\title{
On the near-bottom variability in the northwestern Weddell Sea
}

\author{
M. Schröder ${ }^{\mathrm{a}, *}$, H.H. Hellmer ${ }^{\mathrm{a}}$, J.M. Absy ${ }^{\mathrm{b}}$ \\ a Alfred-Wegener Institute for Polar and Marine Science, PO Box 120161, 27515 Bremerhaven, Germany \\ ${ }^{\mathrm{b}}$ Fundação Universidade do Rio Grande, Rio Grande, Brazil
}

Received 15 June 2001; accepted 17 March 2002

\begin{abstract}
The thermohaline data from the first Brazilian hydrographic cruise to the northwestern Weddell Sea (AR XVIII) revealed significant near-bottom changes in water-column properties over seasonal and interannual time scales. Favorable ice conditions in 2000 allowed a dense station coverage of the area including the main pathways for Weddell Sea deep and bottom waters. The new results are compared with the data from the 1998 German cruise ANT XV/4 and other historical data. A warming of the bottom layer was discovered that was more attributable to short-term seasonal or interannual fluctuations in the formation of cold bottom water than to a long-term trend. There was both consistency and variation between and within seasons. Invariant bottom-water characteristics were observed in different seasons (summer/winter), and variable bottom-water characteristics were observed in the same season (summer) at the same locations. This reduces the possibility of a dominant seasonal effect. Instead, we propose that the intermittent behavior of small cold-water sources along the Weddell Sea's periphery causes the variability measured in the deep northwestern Weddell Sea. The observed variability has consequences for the water-mass export across the South Scotia Ridge, as the absence of the fresher/lighter Weddell Sea Bottom Water south of South Orkney Plateau during AR XVIII might be linked to a reduced ventilation of the deep Scotia Sea. The results of this study show the need for ongoing efforts for establishing a long-term monitoring of this region with global importance.
\end{abstract}

(C) 2002 Elsevier Science Ltd. All rights reserved.

\section{Introduction}

The northwestern Weddell Sea represents a unique hydrographic switch for deep- and bottom-water flow with global importance. All water masses formed or modified in the inner Weddell Sea, a major source region for Antarctic deep and bottom waters (Brennecke, 1921; Carmack, 1971;

\footnotetext{
*Corresponding author.

E-mail address: mschroeder@awi-bremerhaven.de (M. Schröder).
}

Orsi et al., 1999), have to transit this area. We define the inner Weddell Sea as the region south of the line connecting Kapp Norvegia with the tip of the Antarctic Peninsula (AP) (see Fig. 1 in Muench and Hellmer, 2002). From the northwestern Weddell Sea, water masses either escape into Bransfield Strait and further into the Southeast Pacific (Gordon et al., 2000) flow into the Scotia Sea through clefts within the South Scotia Ridge on the way to the South Atlantic (Gordon, 1966; Locarnini et al., 1993) or continue eastwards toward the Indian Ocean abyss (Naveira Garabato 
et al., 2002). The type of water masses leaving the Weddell Sea and their spreading routes are controlled by the highly variable bathymetry of this region (see Smith and Sandwell, 1997), i.e. the location of guiding ridges and associated gaps in a depth range between 2000 and $3000 \mathrm{~m}$.

Newly formed Weddell Sea Bottom Water (WSBW, $\theta \leqslant-0.7^{\circ} \mathrm{C}$ ) ranges over a variety of densities, with the heavier version too deep in the water column to exit the basin, so that its influence is confined to the Weddell-Enderby Basin (Orsi et al., 1993). Only the South Sandwich Trench is sufficiently deep to allow for a northward advance of WSBW beyond $\sim 60^{\circ} \mathrm{S}$. However, even there topographic flow blocking forces most of the WSBW to recirculate (Georgi, 1981), and the Antarctic Circumpolar Current (ACC) obstructs outflow in the northern part of the trench (Whitworth et al., 1994). The deep world ocean is more accessible for water masses spreading on density horizons shallow enough to pass gaps within the Weddell Sea confining ridges (Reid et al., 1977). For the South Scotia Ridge, these water masses represent different varieties of Weddell Sea Deep Water (WSDW, $-0.7^{\circ}<\theta<0^{\circ} \mathrm{C}$ ) and the less dense types of Weddell Sea Bottom Water (WSBW). Both transport ventilated waters (Gordon et al., 2001) through (in descending order of

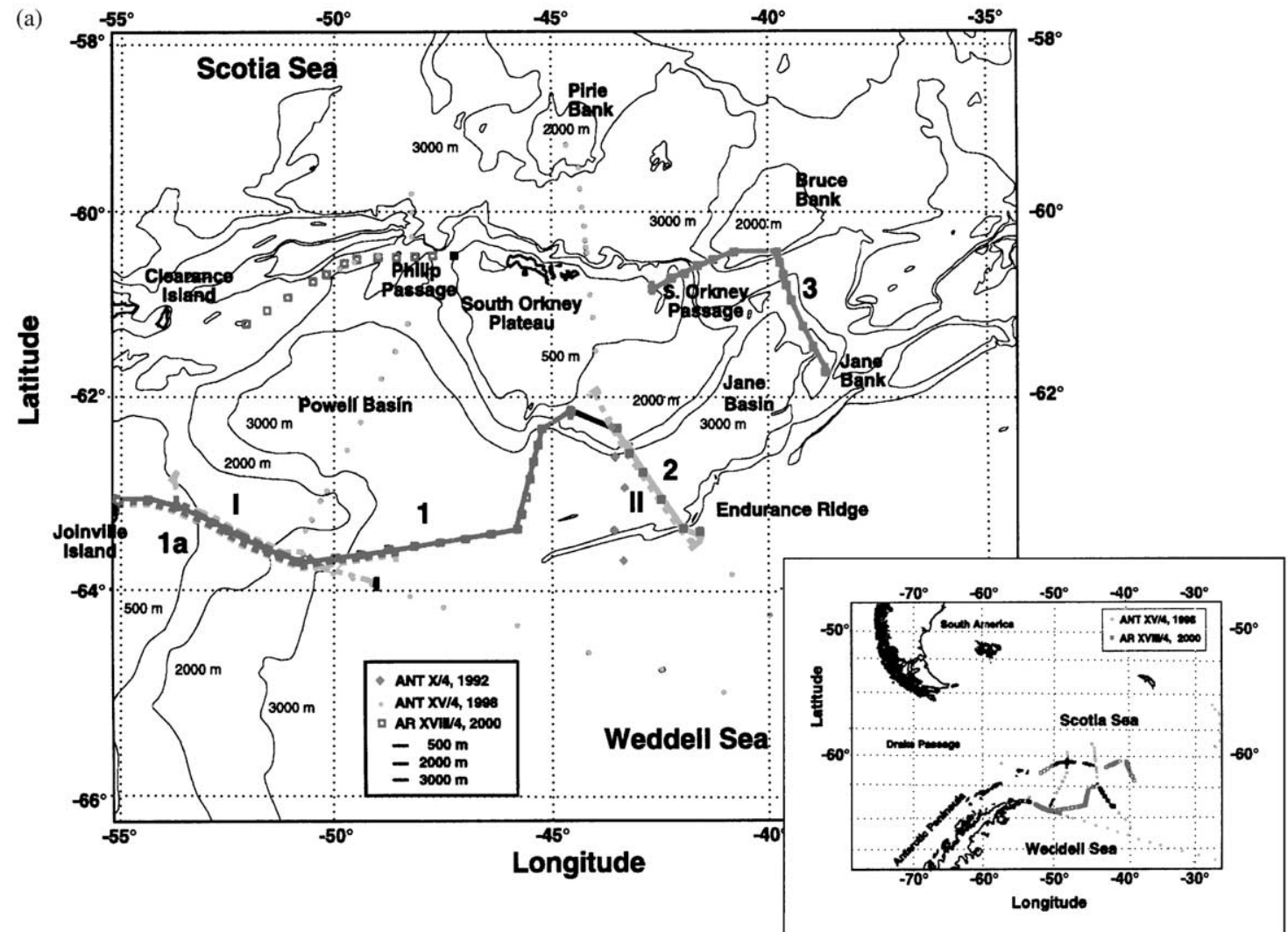

Fig. 1. (a) Geographic map of the DOVETAIL area, and section locations of the cruises ANT XV/4 (I and II) and AR XVIII (1-3). Section 1a is a subsection of Section 1 introduced for a better representation of the northwestern Weddell Sea continental slope. Topographic features mentioned in the text are labeled. Plotted are the 500, 2000, and $3000 \mathrm{~m}$ isobaths. The insert views the investigation area in a larger context. (b) Same as Fig. 1a, but with station locations and station numbers referred to in the text. Twodigit numbers are related to ANT XV/4 (1998), three-digit numbers to AR XVIII (2000) and ANT X/4 (1992), the latter to the west of Section 2 starting with 6 . The position of mooring AWI 207 at station 257 is marked by an arrow. 


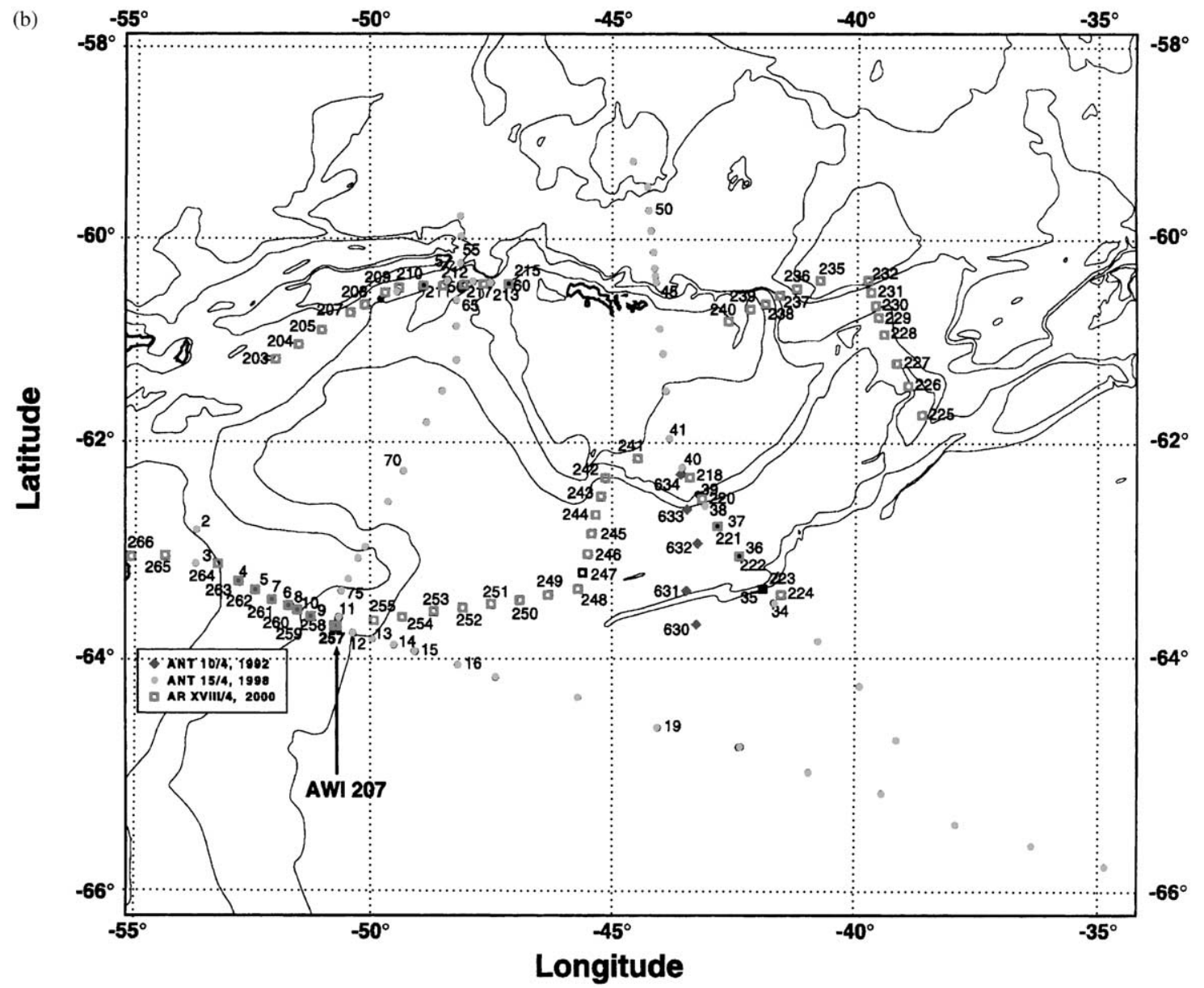

Fig. 1 (continued).

transport rates) Orkney Passage $\left(40^{\circ} \mathrm{W}\right)$, Philip Passage $\left(\sim 49^{\circ} \mathrm{W}\right)$, and various narrower passages in the eastern part of the South Scotia Ridge (Naveira Garabato et al., 2002). Significant control is exerted on the flow by the sill at the southwestern entrance of Powell Basin and the Endurance Ridge southeast of the South Orkney Plateau (SOP) (Schodlok et al., 2002) (Fig. 1a).

In addition to the spatial variability, the water mass characteristics of the northwestern Weddell Sea are also subject to temporal variations. These range from seasonal to long-term and affect both deep and bottom waters (Foster and Middleton, 1979; Fahrbach et al., 2001; Robertson et al., 2002). However, it is still speculative whether the changes on time scales longer than seasonal are indicators for a long-term trend or an expression of a longer-period variability of the system. It is also unclear whether the variability is of regional, basin-scale or circumpolar origin, i.e. caused by processes on the Weddell Sea continental shelf (Grosfeld et al., 2001), by changes within the Weddell Gyre (Schröder and Fahrbach, 1999) or by periodicities of the Antarctic Circumpolar Current (White and Peterson, 1996) or the Antarctic Coastal Current (Beckmann and Timmermann, 2001).

This study describes the thermohaline data from CTD measurements during the first Brazilian hydrographic cruise (AR XVIII) onboard NApOc 
Ary Rongel to the northwestern Weddell Sea from 23 January to 9 February, 2000, as part of the DOVETAIL project (Muench and Hellmer, 2002). Favorable ice conditions allowed an extensive station coverage of the area with sections across the southern entrance of Powell Basin, from the SOP into the central Weddell Sea, and across the major clefts of the western and central South Scotia Ridge (Fig. 1a). The results are compared primarily with the data of the cruise ANT XV/4 (April 1998) onboard FS Polarstern, but data sets from other years (German cruises) (July 1992 [ANT X/4], February 1993 [ANT X/7], and February 1995 [ANT XII/3]) were used to investigate interannual variability of deep- and bottom-water characteristics in the northwestern Weddell Sea.

\section{Data}

\subsection{Data processing}

During the cruise AR XVIII hydrographic data were collected using a Sea-Bird 911plus CTD system and a SBE 32 carrousel equipped with 12 51 bottles. The sensors were calibrated both prior (August 1999) and after (June 2000) the cruise at Sea-Bird Electronics Inc. Temperature and pressure sensors were stable while the conductivity sensor had a $0.0017 /$ month drift over the 10month period. The conductivity was additionally corrected by means of salinity analysis on water samples 4.5 months after the cruise using a Guildline Autosal 8400 B and IAPSO Standard Seawater (P135). The resulting $\theta / S$-diagrams were plotted and compared with CTD profiles of recent cruises to check whether the new data fits the linear relationship for WSDW of the inner Weddell Sea. The data accuracies were $2 \mathrm{mK}$ (temperature), $2 \mathrm{dbar}$ (pressure), and 0.003 (salinity).

For the CTD stations of Polarstern cruise ANT XV/4 (1998), Triton ICTD probes from Falmouth Scientific Instruments were used. Water samples were analyzed for salinity using a Guildline Autosal 8400 B. The accuracy of the 1998-data is $2 \mathrm{mK}$ (temperature), $2 \mathrm{dbar}$ (pressure), and 0.002 (salinity). For a detailed description of the data processing see Fahrbach (1999). In addition, data from some hydrographic stations (see also Fig. 1b) of the Polarstern winter cruise ANT X/4 (July 1992) (Schröder, 1994), and ANT XII/3 (February 1995) (Schröder, 1997) were used.

\subsection{Data description (AR XVIII)}

Section 1 (Fig. 1a) ran from the tip of the AP in an east-southeast direction down the continental slope into the deep Weddell Sea towards stat. 257 with a water depth of $2500 \mathrm{~m}$ (Fig. 1b). This station was at the position of mooring AWI 207, which continuously recorded temperatures, salinities, and currents from May 1996 to March 1998 (von Gyldenfeldt et al., 2002; Fahrbach et al., 2001). From here, Section 1 crossed the southern entrance of Powell Basin following a more easterly and northerly direction towards the SOP until the water depth shallowed to $\sim 700 \mathrm{~m}$. The western part of the section matched the German Weddell Sea section occupied in 1989, 1990, 1993, 1996, and 1998.

Section 1 resolves the water masses entering (west) and leaving (east) Powell Basin and, at deeper levels, the WSBW flowing eastward within the northern limb of the Weddell Gyre (Figs. 2ad). The cold and fresh lens hugging the continental slope marks newly formed WSBW. Near-bottom (within $50 \mathrm{~m}$ ) potential temperatures along the whole section were slightly below $-1.1^{\circ} \mathrm{C}$, with a minimum of $\theta=-1.125^{\circ} \mathrm{C}$ at stat. 254. Within this thin bottom layer the salinity decreased towards the bottom to $S \geqslant 34.625$. At stat. 258 and 259 the salinity dropped to $S=34.615$. The tilt of the isolines (Fig. 2a and b) indicates a dominant cyclonic circulation in Powell Basin (Gordon et al., 2001), with inflow along the continental slope off the AP and return flow along the western slope of South Orkney Plateau. East of stat. 253, bottom temperatures were always above $\theta \approx-1.0^{\circ} \mathrm{C}$ with the coldest bottom temperature at stat. 250 of $\theta=-1.02^{\circ} \mathrm{C}$ and a salinity of $S=$ 34.630 .

At shallower levels, the core of the Warm Deep Water $\left(\theta>0.6^{\circ} \mathrm{C}\right)$ is seen at most of the stations with bottom depths exceeding $2000 \mathrm{~m}$. Maximum temperature on this transect was measured at 
stat. 253 with $\theta=0.704^{\circ} \mathrm{C}$ at a depth of $407 \mathrm{~m}$. In Fig. 2c, the shallowest stations with an almost linear $\theta / S$ relationship indicate potential source waters which might contribute to the fresh and cold WSBW component defined by Gordon et al. (2001) as ventilated WSBW. Due to the summer season and the low sea-ice concentration $(\leqslant 1 / 10)$, potential temperatures on the continental shelf

(a)

\section{AR XVIII - section 1}
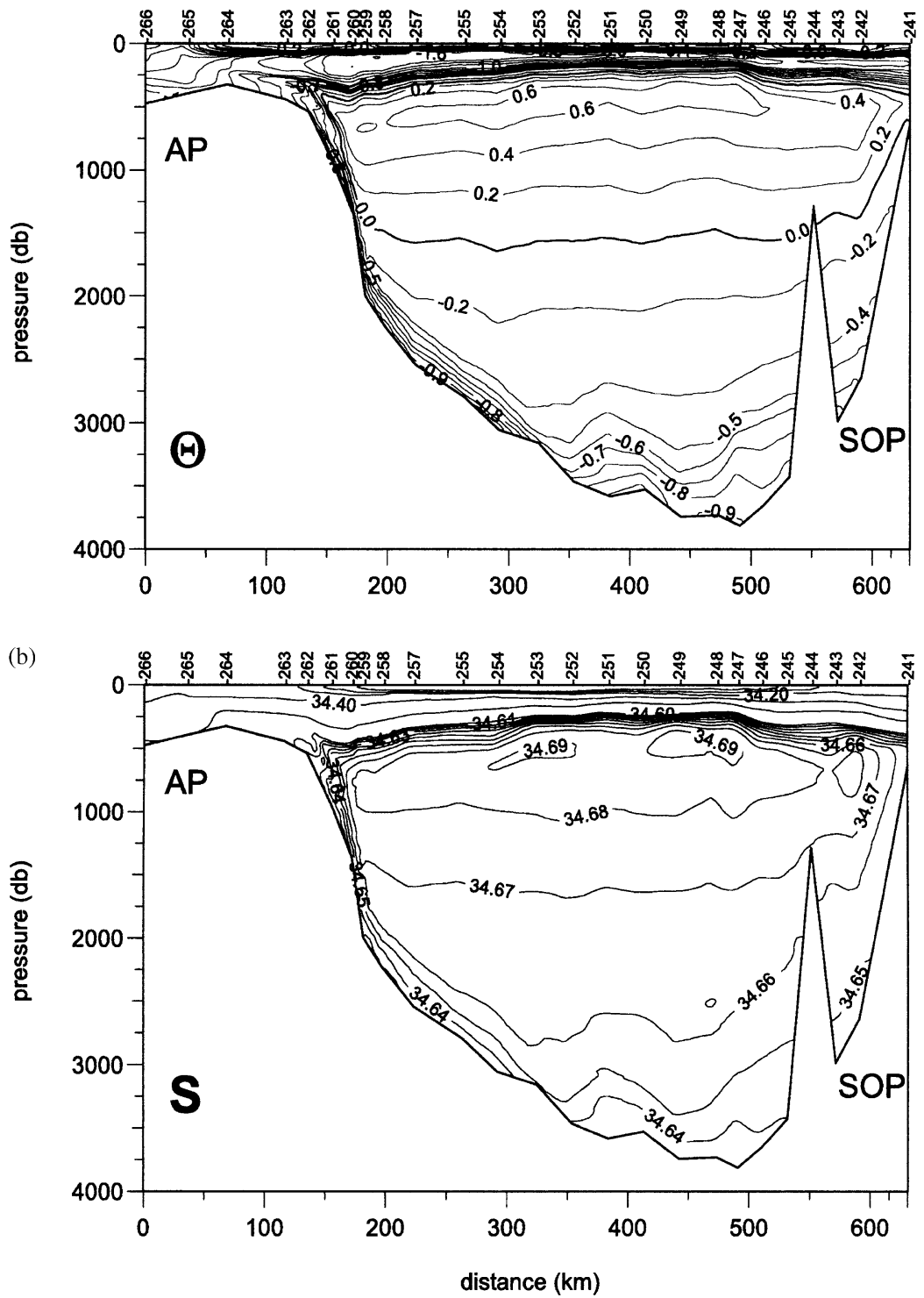

Fig. 2. (a) Potential temperature $(\theta)$ distribution along Section 1 of cruise AR XVIII (2000) from the continental shelf off AP to the eastern slope of SOP. Station locations are labled by cruise station numbers above the uppermost horizontal axis. (b) Same as Fig. 2a, but for salinity $(S)$. (c) Potential temperature vs. salinity $(\theta / S)$ diagram for the western part (stat. 266-253) of Section 1 covering the flow along the continental slope off the AP into Powell Basin. Isopycnals are drawn relative to the surface $\left(\sigma_{0}\right)$ and to $2000 \mathrm{~m}\left(\sigma_{2}\right)$. (d) Potential temperature vs. salinity $(\theta / S)$ diagram for the eastern part (stat. 253-241) of Section 1 covering the flow along the southern slope of the SOP out of Powell Basin. Isopycnals are drawn relative to the surface $\left(\sigma_{0}\right)$ and to $2000 \mathrm{~m}\left(\sigma_{2}\right)$. 
(c) AR XVIII 266 - 253
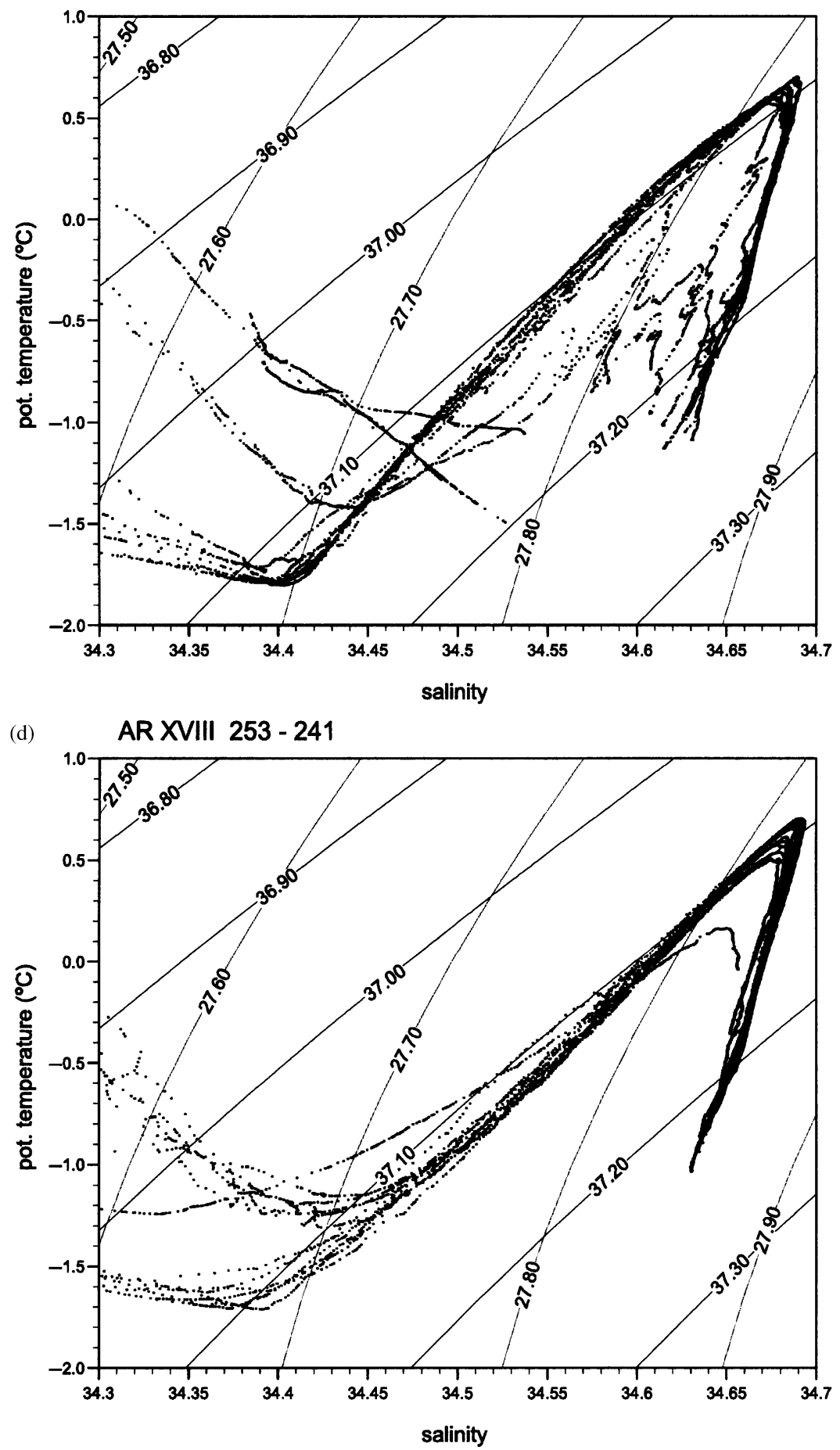

Fig. 2 (continued). 
were above the surface freezing point. Model results suggest that these waters enter the Bransfield Strait basins to the north instead of the deep Weddell Sea or Powell Basin (Schodlok et al., 2002). Significant differences between the basin's inflow (Fig. 2c) and outflow (Fig. 2d) existed at shallow depth, due to the shelf break mixing restricted to the peninsula region, and near the bottom. Here, the broad range of WSBW characteristics reduced from west to east to a single
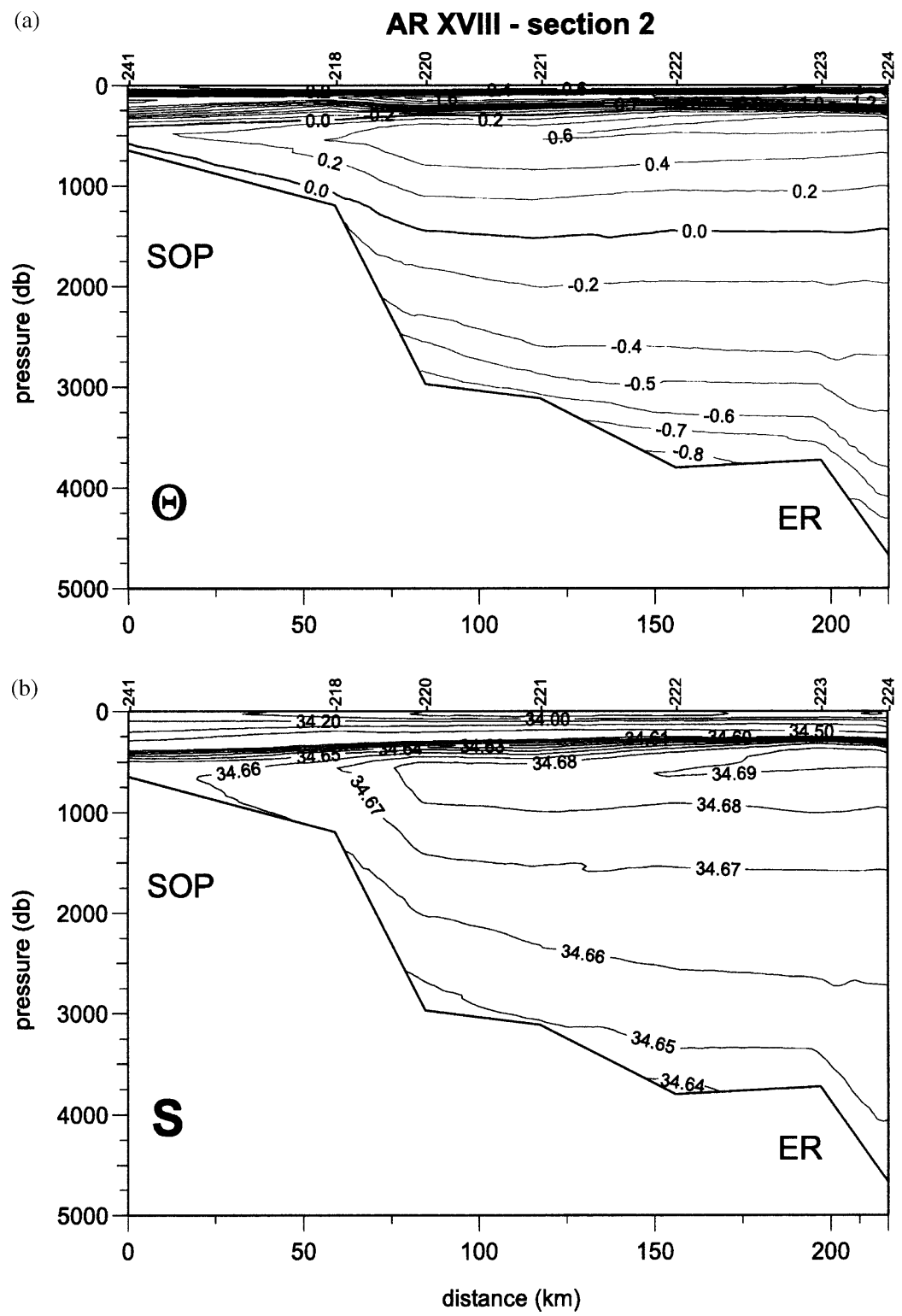

Fig. 3. (a) Potential temperature $(\theta)$ distribution along Section 2 of cruise AR XVIII across the southeastern slope of SOP and Endurance Ridge (ER). Station locations are labled by cruise station numbers above the uppermost horizontal axis. (b) Same as Fig. 3a, but for salinity $(S)$. (c) Potential temperature vs. salinity $(\theta / S)$ diagram for Section 2 . Note the small salinity differences for great depth representing stations on either side $(\mathrm{N}=$ north $/ \mathrm{S}=$ south $)$ of Endurance Ridge. Isopycnals are drawn relative to the surface $\left(\sigma_{0}\right)$ and to $2000 \mathrm{~m}\left(\sigma_{2}\right)$. 


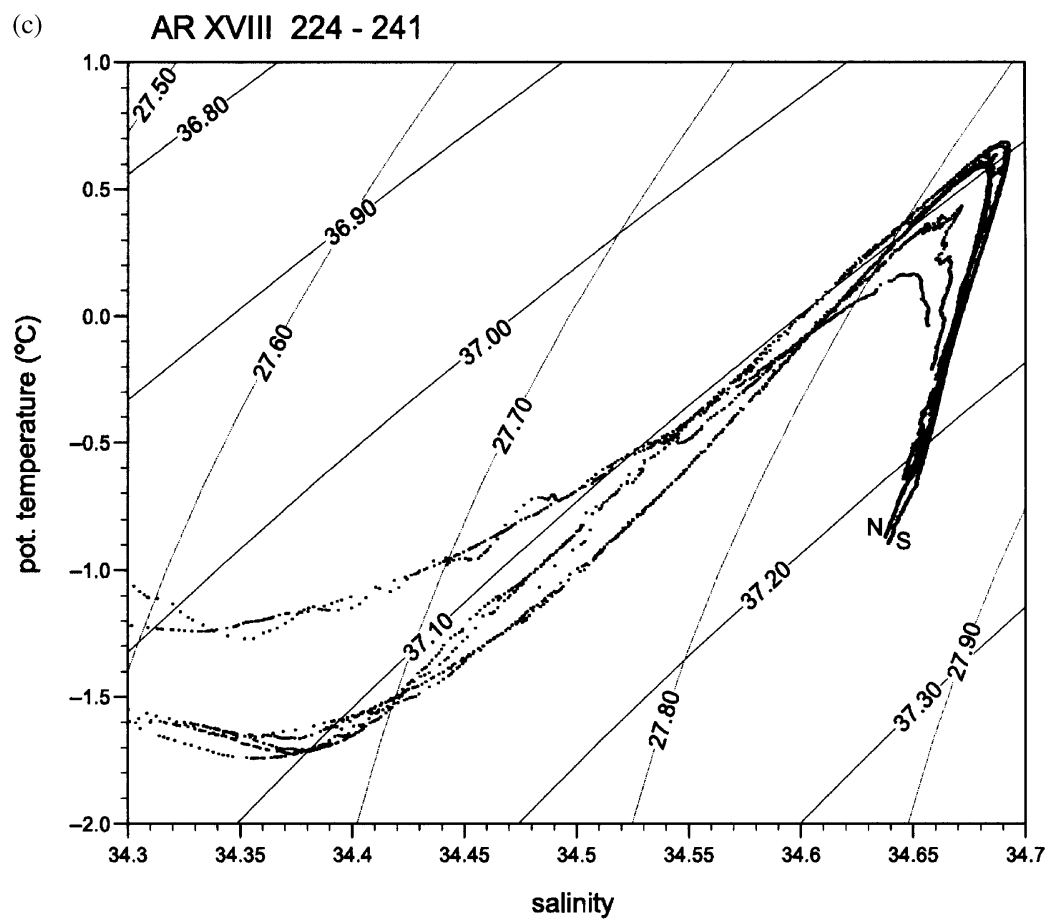

Fig. 3 (continued).

type representing the saltier version entering Powell Basin.

Section 2 (Fig. 1a) ran from the SOP to the southeast towards the deep Weddell Basin (Figs. 3a-c). The temperature and salinity distributions (Figs. 3a and b) show a cold and fresh bottom layer on both sides of Endurance Ridge. Minimum values were $\theta=-0.865^{\circ} \mathrm{C}$ and $S=$ 34.637 at stat. 222 to the north, and $\theta=$ $-0.895^{\circ} \mathrm{C}$ and $S=34.639$ at stat. 224 to the south of the ridge at $\sim 3300$ and $\geqslant 4000 \mathrm{~m}$, respectively. The differences in potential temperature and salinity between both stations were very small $\left(\Delta \theta=0.03^{\circ} \mathrm{C}, \Delta S=0.005\right)$ for the deepest 400 $600 \mathrm{~m}$ (Fig. 3c). This represents a significant change in water-mass composition compared to the measurements in 1992 (Schröder, 1994) and 1998. In both years, the near-bottom characteristics differed north and south of the ridge by $\Delta \theta \geqslant 0.15^{\circ} \mathrm{C}$ and $\Delta S \geqslant 0.15$ (this phenomenon will be discussed in detail later together with Figs. 7 and 12).
Section 3 (Fig. 1a) crossed two deep gaps of the South Scotia Ridge on both sides of Bruce Bank, which serve as possible gateways for dense water masses to escape from the Weddell Sea into the Scotia Sea (Figs. $4 \mathrm{a}-\mathrm{c}$ ). The bottom temperature and salinity in both passages indicate a fresh, cold WSBW/WSDW mixture. The mixing between WSBW and WSDW occurs as the bottom water flows along the "rough" slopes of the SOP. At the bottom of Orkney Passage a minimum temperature of $\theta=-0.62^{\circ} \mathrm{C}$ and a salinity of $S=34.648$ (stat. 238) were measured, whereas in Bruce Passage to the east (stat. 228) these values were lower, $\theta=-0.739^{\circ} \mathrm{C}$ and $S=34.643$. The bottom waters of both gaps originate from the northern WSBW layer of Section 2, since their $\theta / S$ characteristics (Fig. 4c) coincide with those of stat. 222 (marked "N" in Fig. 3c). This confirms the idea of sole supply from the northern WSBW layer due to a screening of the deep Jane Basin by the Endurance Ridge. Due to a northward shoaling of the topography, the export through Bruce Passage 
is limited (Naveira Garabato et al., 2002; Schodlok et al., 2002). The maximum temperature of $\theta>0.6^{\circ} \mathrm{C}$ in the depth range $500-1000 \mathrm{~m}$ documents the influence from the south as the values are typical for the Weddell and not for the Scotia seas.

\subsection{Data comparison between AR XVIII (2000)} ANT XVI4 (1998)

In order to detect interannual variability in the northwestern Weddell Sea, we compared the
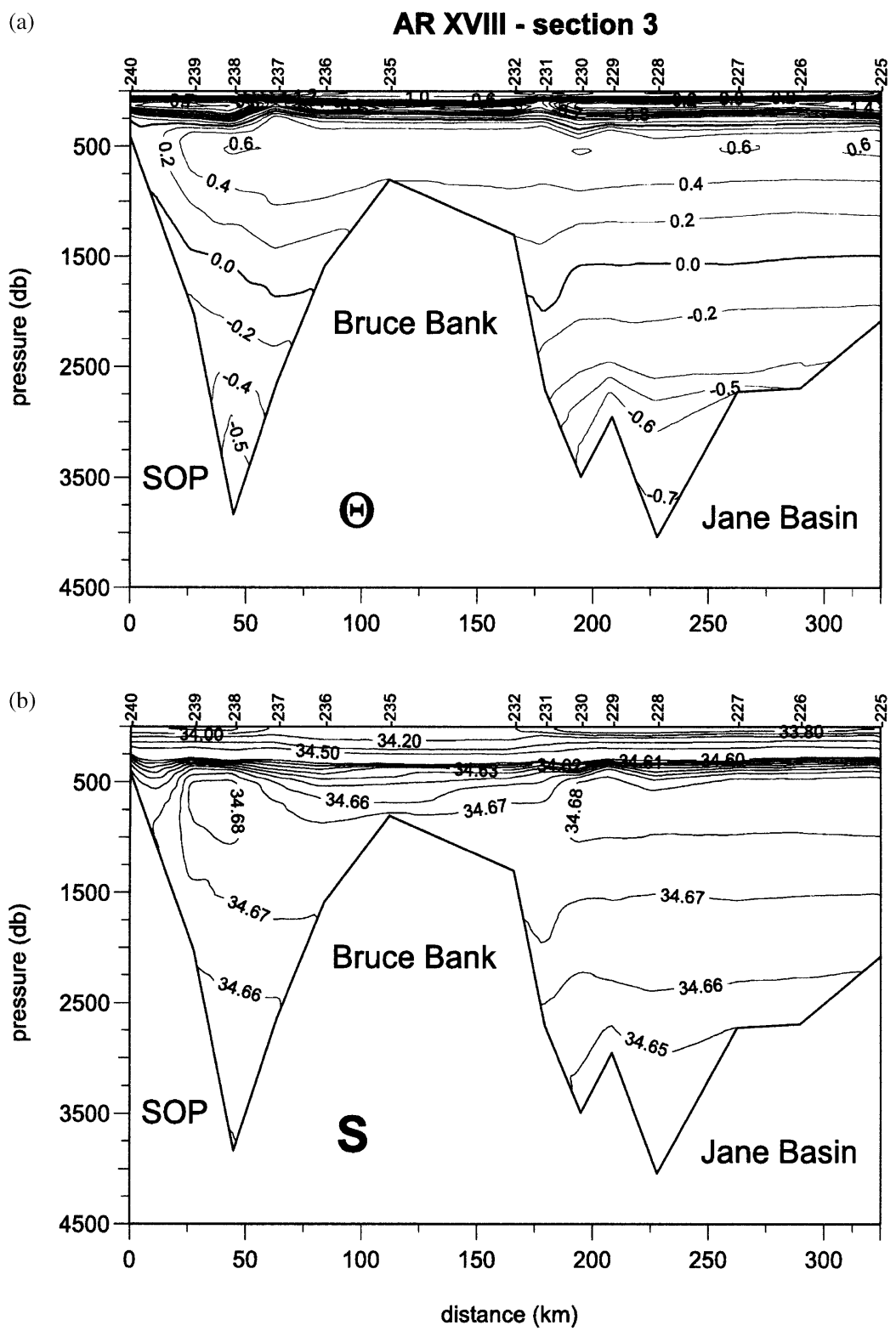

Fig. 4. (a) Potential temperature $(\theta)$ distribution along Section 3 of cruise AR XVIII across the northeastern slope of SOP and two deep passages on both sides of Bruce Bank assumed to be main routes for water masses escaping from the Weddell into Scotia seas. Station locations are labled by cruise station numbers above the uppermost horizontal axis. (b) Same as Fig. 4a, but for salinity $(S)$. (c) Potential temperature vs. salinity $(\theta / S)$ diagram for Section 3. Isopycnals are drawn relative to the surface $\left(\sigma_{0}\right)$ and to $2000 \mathrm{~m}\left(\sigma_{2}\right)$. 


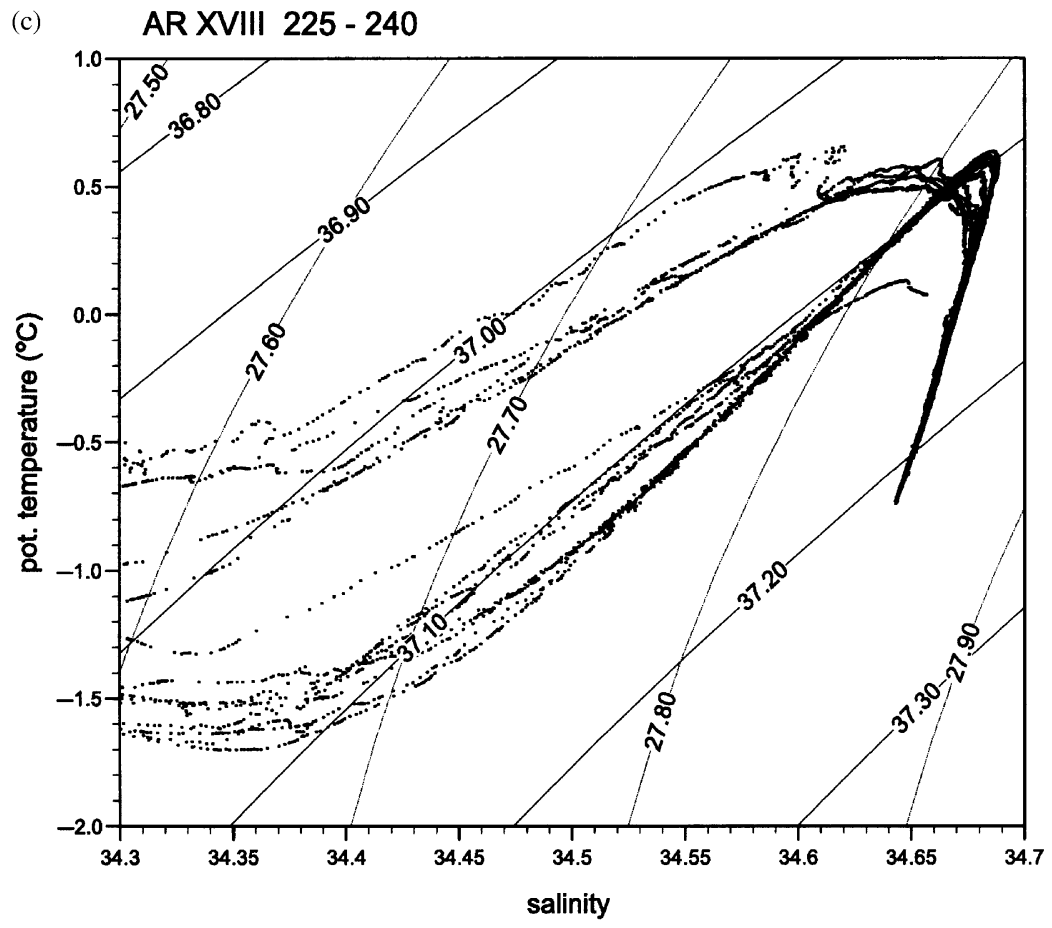

Fig. 4 (continued).

AR XVIII data with data from the cruise ANT XV/4 along Sections 1/I and 2/II (Fig. 1a). Vertical sections of $\theta$ and $S$ are shown in more detail for the western shelf/slope region for the years 1998 (Fig. 5a and b) and 2000 (Fig. 5c and d). Except for the three easternmost stations, profiles of both years were taken at the same location so that regional differences should be eliminated (for station positions see Fig. 1b).

The cold, fresh bottom layer along the continental slope was half as thick in 2000 (Fig. 5c and d) as it was in 1998 (Fig. 5a and b), and was accompanied by higher near-bottom $\theta$ values with a maximum difference of $0.36^{\circ} \mathrm{C}$ for the lowest $80 \mathrm{~m}$ between stat. $257\left(\theta=-0.964^{\circ} \mathrm{C}\right)$ in 2000 (Fig. 5c) and stat. $011\left(\theta=-1.323^{\circ} \mathrm{C}\right)$ in 1998 (Fig. 5a). The salinity difference of 0.02 was restricted to the depth interval $80-400 \mathrm{~m}$ above bottom (saltier in 2000). For the bottom layer (lowest $80 \mathrm{~m}$ ), this difference vanished resulting in equal bottom values of $S=34.628 / 34.629$ (Fig. 5b and $d)$. Near the steepest part of the continental slope (stat. 260 and 259 compared with 008, 010) the WSBW layer almost disappeared in 2000 . The temperature maximum $\left(\theta>0.6^{\circ} \mathrm{C}\right)$ did not significantly change its position (vertically and distance to shelf break) and value, but the salinity maximum $(S>34.68)$ was thicker and located closer to the slope front.

The $\theta$ and $S$ changes at the southern flank of the SOP can be seen by comparing data from 1998 (Fig. 6a and b) with those from 2000 (Fig. 6c and d). In general, the sections show only minor differences for $\theta$ and $S$ above $3000 \mathrm{~m}$. North of Endurance Ridge (stat. 222/036) below $3200 \mathrm{~m}$, the WSBW branch, with $\theta$ and $S$ values significantly less than $\theta<-0.8^{\circ} \mathrm{C}$ and $S<34.640$, respectively, was absent in 2000. The differences in WSBW characteristics below $\theta=-0.66^{\circ} \mathrm{C}$ are more obvious in the $\theta / S$-diagram (Fig. 7) which illustrates that in 2000 (hatched area) the salty (and warmer) WSBW component dominated both sides of Endurance Ridge. The near-bottom salinity range across the ridge lessened from 0.016 in 1992 and 
1998 to 0.005 in 2000 . Two years before, this salty component was restricted to the south of the ridge, with an additional fresher and colder WSBW to the north. The gray shaded area separating the different WSBW types is a data void. This can be explained by the topographic control of the ridge further upstream. With a crest height less than $2000 \mathrm{~m}$ water depth, Endurance Ridge prevents mixing of the two deep WSBW cores. In addition, the data void confirms the different routes WSBW cores of different density travel in the northwestern Weddell Sea (e.g., Schodlok et al., 2002).
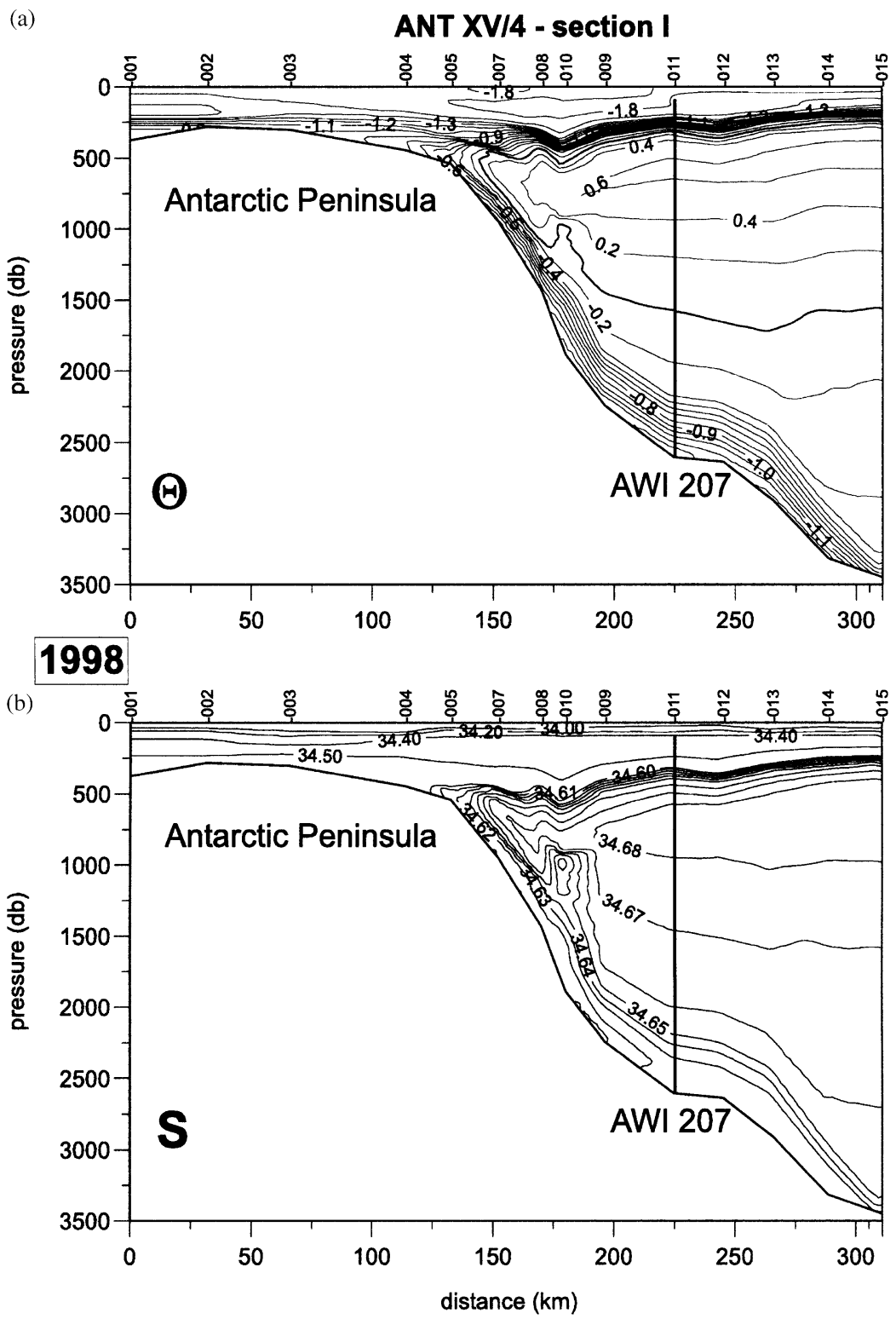

Fig. 5. Comparison of potential temperature distribution between Section I of year 1998 (a, b) and sub-Section 1a of year 2000 (c, d). Positions of stations 257-263 (AR XVIII) agree with stations 4-11 (ANT XV/4). The vertical line marks the position of mooring AWI 207. Corresponding stations of the cruises ANT XV/4 and AR XVIII are labeled at the top. 

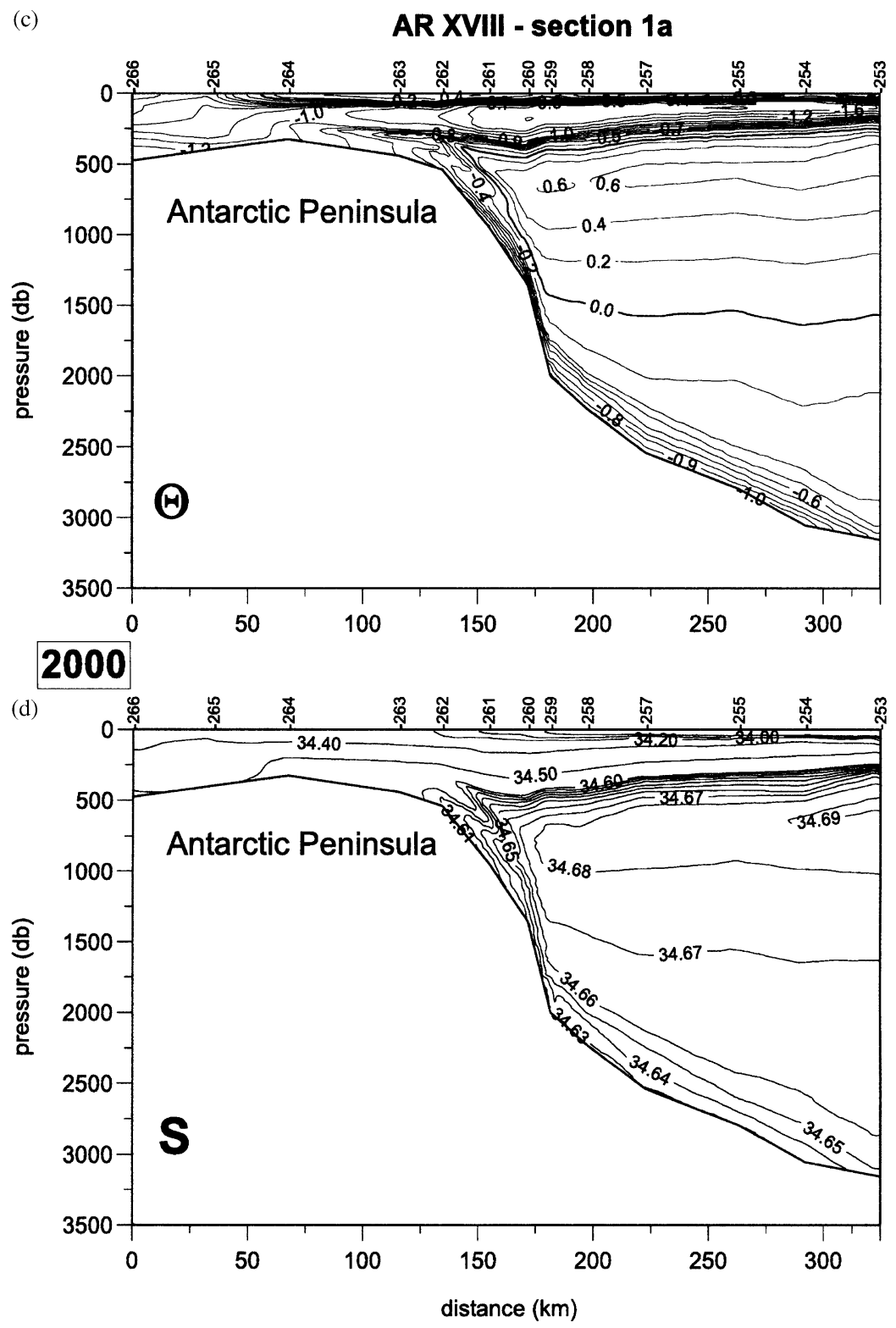

Fig. 5 (continued).

Above $\theta=-0.36^{\circ} \mathrm{C}$, salinity variations are small for all years, $\Delta S=0.005$ (Fig. 7).

Despite minor spatial differences, both data sets (ANT XV/4 and AR XVIII) are sufficient for an interannual comparison of the horizontal distribution of the bottom potential temperature, here assumed to be an indicator for the strength of WSBW production and the pathways of the cold bottom water. Fig. 8a shows the situation in 1998, which is almost identical to the distribution known from historical data (e.g. Gordon et al., 2001). The coldest water with $\theta \leqslant-1.3^{\circ} \mathrm{C}$ was found along 
the continental slope off the AP in the depth range 2500-3000 m (stat. 011-013). This water flows with the cyclonic gyre circulation northwards and is $0.3^{\circ} \mathrm{C}$ warmer as it enters and fills the entire deep Powell Basin with temperatures below $\theta=-1.0^{\circ} \mathrm{C}$. After leaving the basin to the east along the southern slope of South Orkney Plateau, the water reaches the region covered by Section 2 . There, Endurance Ridge divides the plume into two branches. Although on both sides of the ridge bottom values are near $-1.0^{\circ} \mathrm{C}$, the coldest temperatures of $\theta<-1.0^{\circ} \mathrm{C}$ are only seen on the southern flank. The 2000-distribution (Fig. 8b) looks quite different. Bottom potential
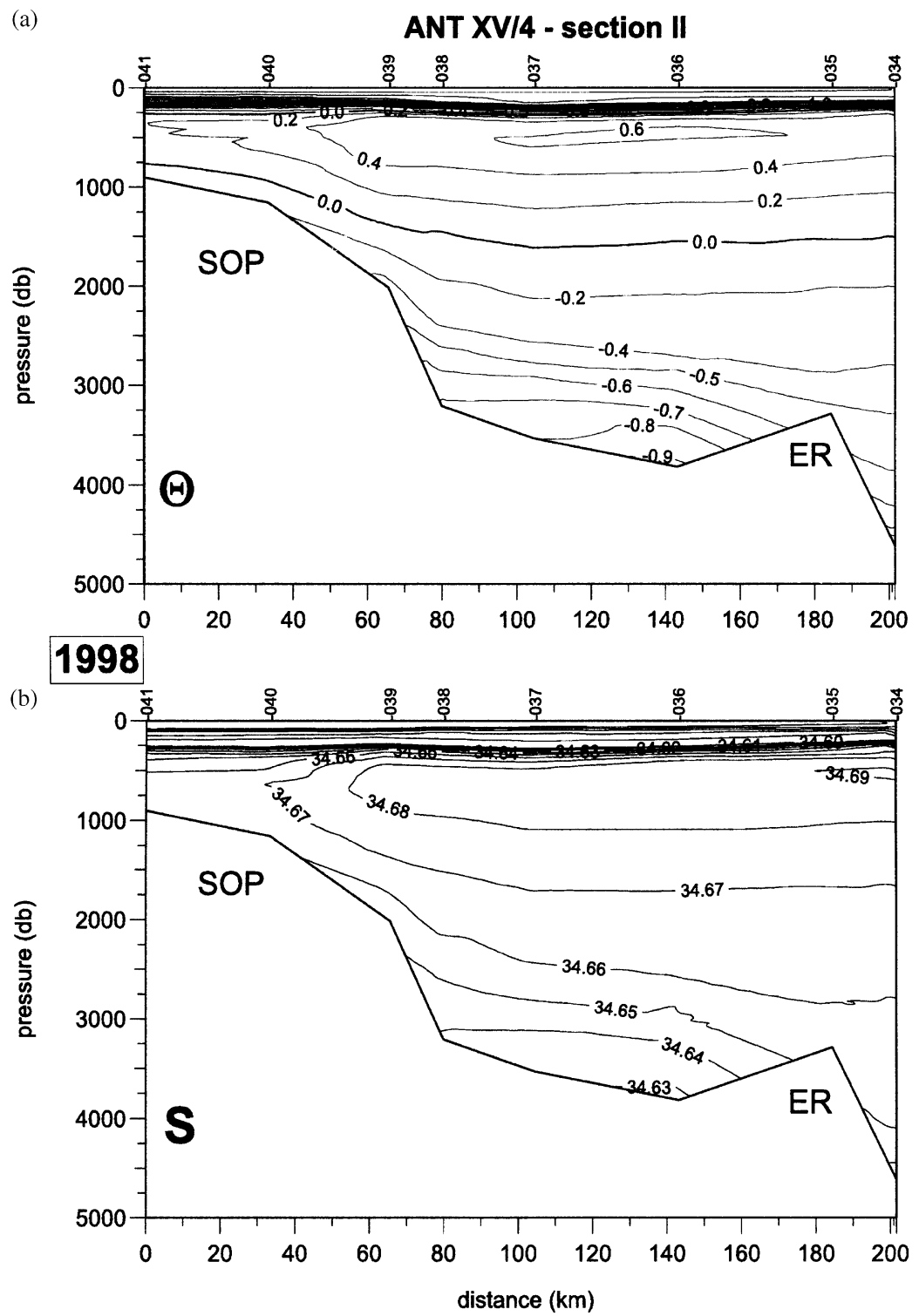

Fig. 6. Comparison of potential temperature distribution between Section II of year 1998 (a, b) and Section 2 of year 2000 (c, d). Positions of stations 224-218 (AR XVIII) agree with stations 34-40 (ANT XV/4). Corresponding stations of the cruises ANT XV/4 and AR XVIII are labled at the top. 

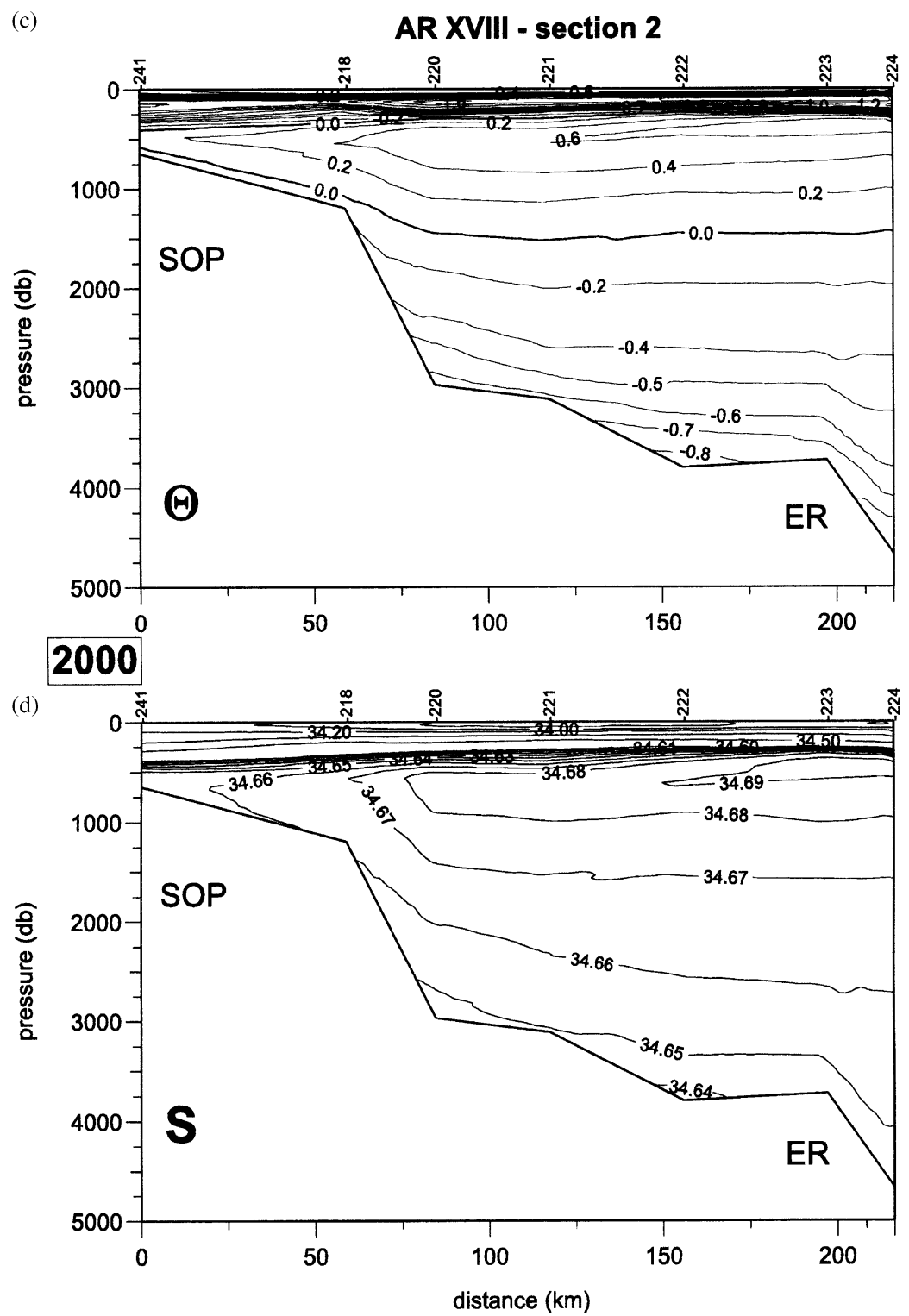

Fig. 6 (continued).

temperatures of $\theta<-1.0^{\circ} \mathrm{C}$ are measured only at a few stations near the AP, but they are absent further downstream. The $\theta=-1.0^{\circ} \mathrm{C}$ isotherm now runs in a more east/west direction towards the southwestern tip of Endurance Ridge, resulting in temperature increases of $>0.3^{\circ} \mathrm{C}$ and $0.2^{\circ} \mathrm{C}$ near the peninsula and south of the SOP, respectively.
We have to admit that a direct comparison of the bottom temperatures in central Powell Basin is ambiguous due to the lack of 2000-observations in that region. However, preliminary data from 2001 field work reveal that the $-0.8^{\circ} \mathrm{C}$ isotherm extends into Powell Basin as indicated by the dashed line in Fig. 8b. 


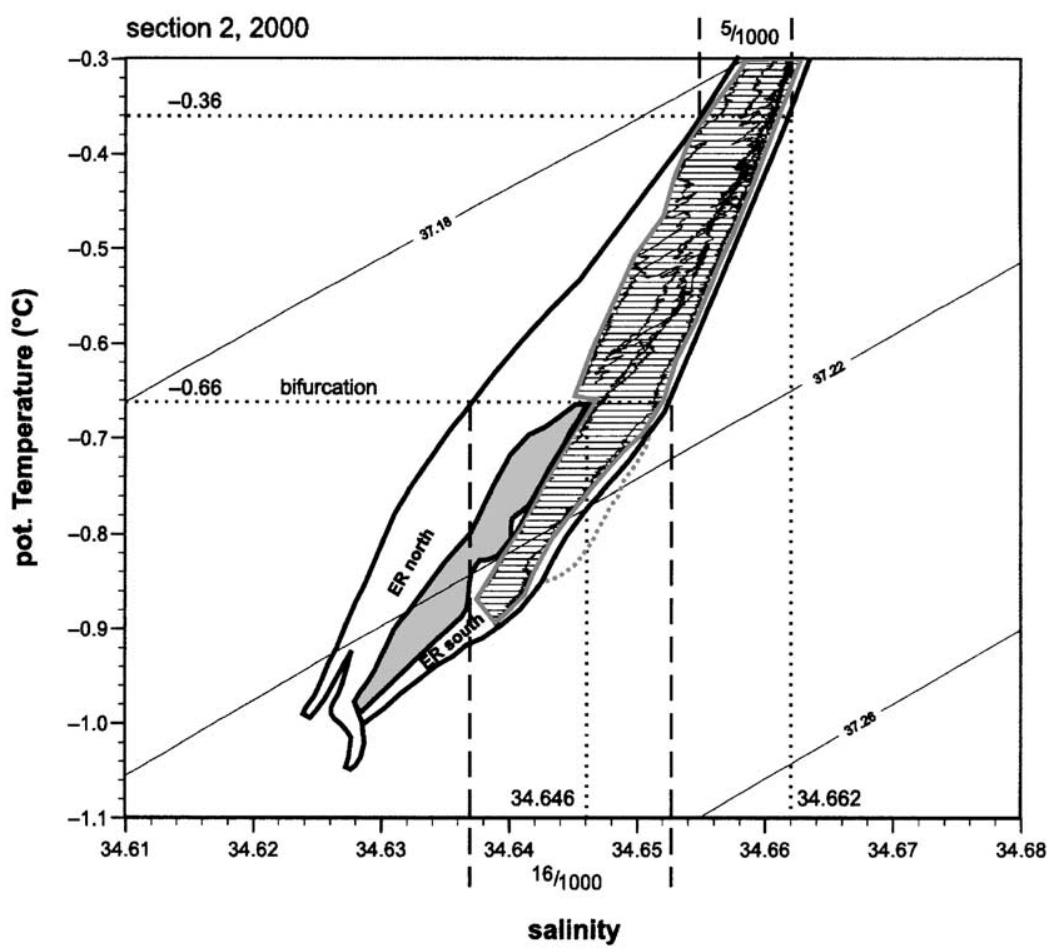

Fig. 7. Schematic potential temperature vs. salinity $(\theta / S)$ diagram for the near-bottom layer along Section 2 . The bold line represents the envelope of all historical data, the hatched area covers the AR XVIII range as shown by representative curves. As a reference, the dotted line represents (salty) curves as observed for the inner Weddell Sea $(>4500 \mathrm{~m})$. Outer dotted lines mark the beginning of the divergence of the curves at $\theta=-0.36$ with $\Delta S>0.005$; inner dotted lines mark the Endurance Ridge induced separation at $\theta=-0.66$ with $\Delta S>0.016$ into a fresher/saltier (ER north/ER south) branch. Isopycnals are drawn relative to $2000 \mathrm{~m}$.

\section{Discussion}

The following arguments are focused on the question whether the observed warming of the bottom layer from 1998 to 2000 is due to a longterm warming trend in WDW and upper WSDW in the Weddell Sea (Robertson et al., 2002) or subject to a variability on shorter timescales inherent in the bottom water formation process along the Weddell Sea's western rim (Fahrbach et al., 2001).

The differences in bottom water characteristics, especially the strong increase in temperature, might be caused by a varying composition of source waters involved in the bottom-water formation process at the continental shelf break of the inner Weddell Sea. This might reflect either a variable number of dense water production sites with slightly different characteristics or the same sources producing different amounts (volumes). The variability is illustrated by the $\theta / S$-diagram composed of selected CTD stations from different years located on Sections I and 1a (Fig. 9). It allows for an analysis of the WSBW components and provides a possible reason for the different near-bottom $\theta / S$-curvatures in specific years.

The typical $\theta / S$-curves for depths up to $2500 \mathrm{~m}$ along Sections I and 1a are supplemented by $\theta / S$ curves from the Filchner Trough outflow (Fig. 9). The latter represents the densest waters formed by mixing of saline shelf water with Ice Shelf Water spilling over into the deep Weddell Basin (Grosfeld et al., 2001). For temperatures below $-0.5^{\circ} \mathrm{C}$, the 1998 data show a tendency towards lower salinities when approaching the bottom layer, but with a clear near-bottom trend toward higher salinities 
(a)

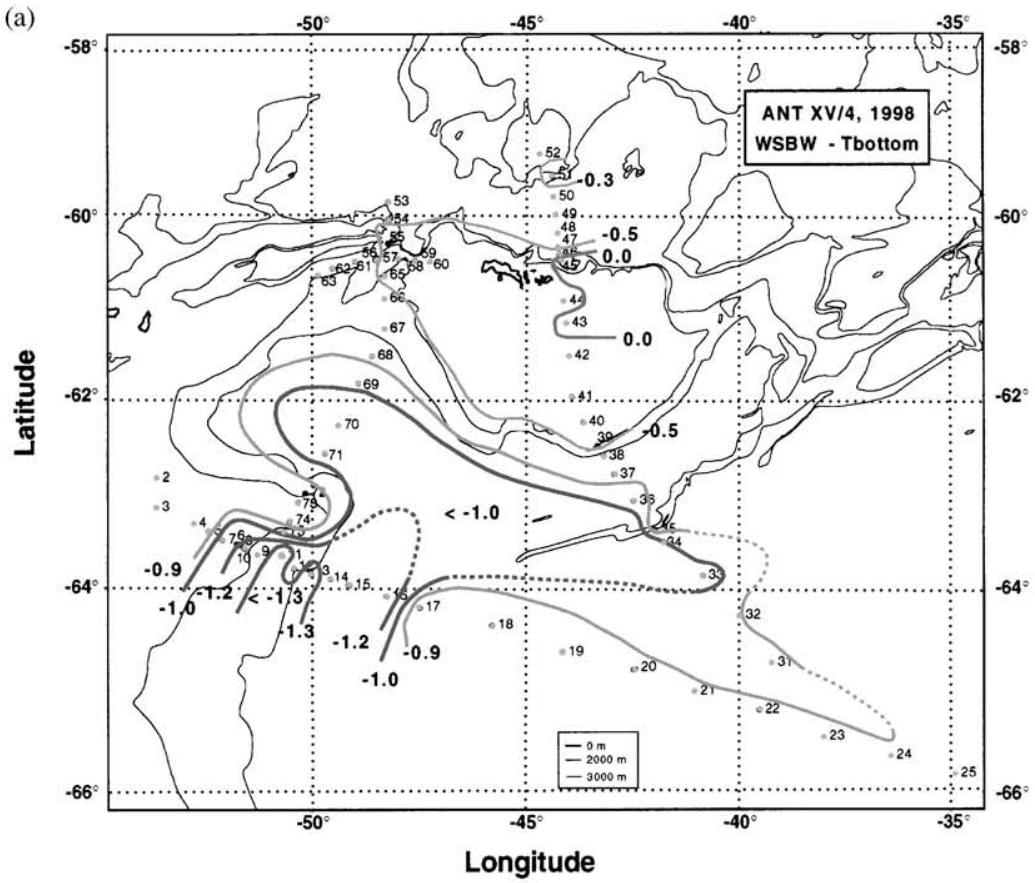

(b)

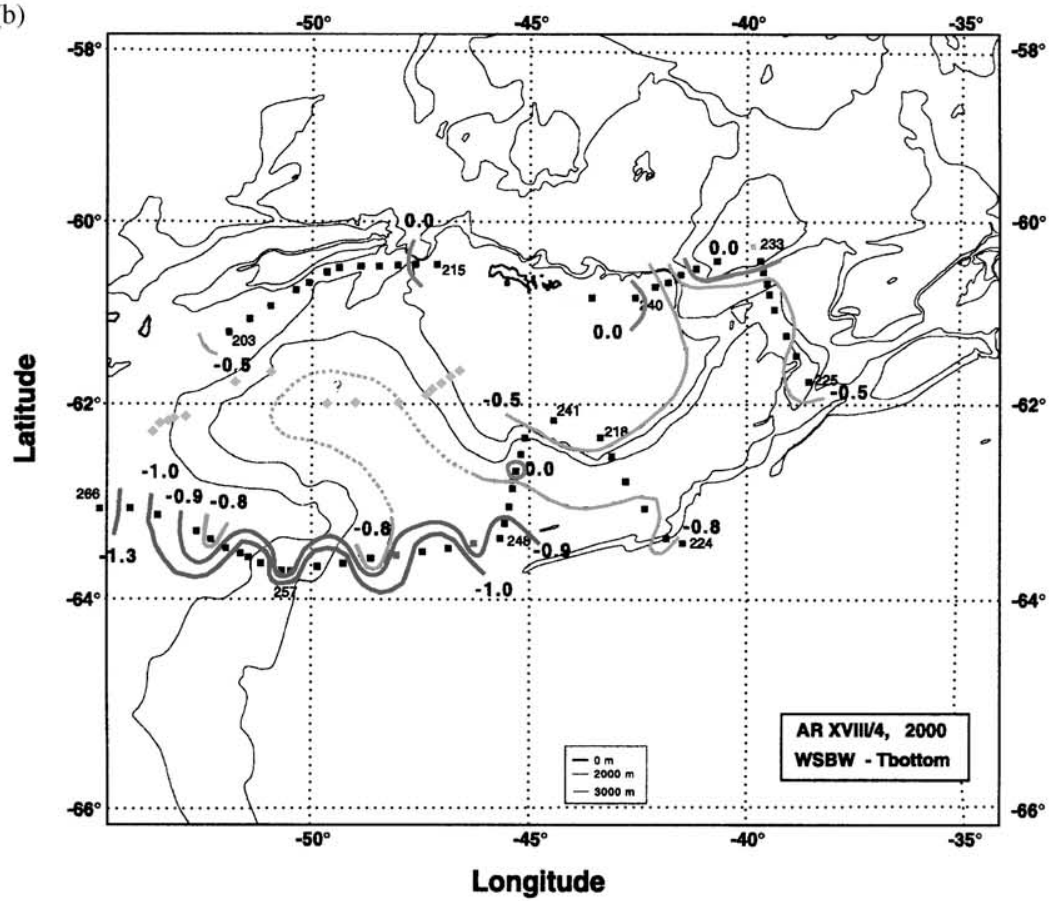

Fig. 8. Comparison of bottom potential temperature distribution in the northwestern Weddell Sea between the years 1998 (a) and 2000 (b). Isolines not supported by data and away from the guiding topography are dotted. The light shaded diamonds along $\sim 69^{\circ} \mathrm{S}$ in $(\mathrm{b})$ represent stations from cruise AR XIX (2001). This data shows a warming indicated by the extension of the $\theta=-0.8^{\circ} \mathrm{C}$ isotherm into central Powell Basin (no data in 2000). The isotherm is drawn as dashed line and marked with (?) because of the 1-year difference between the cruises. 


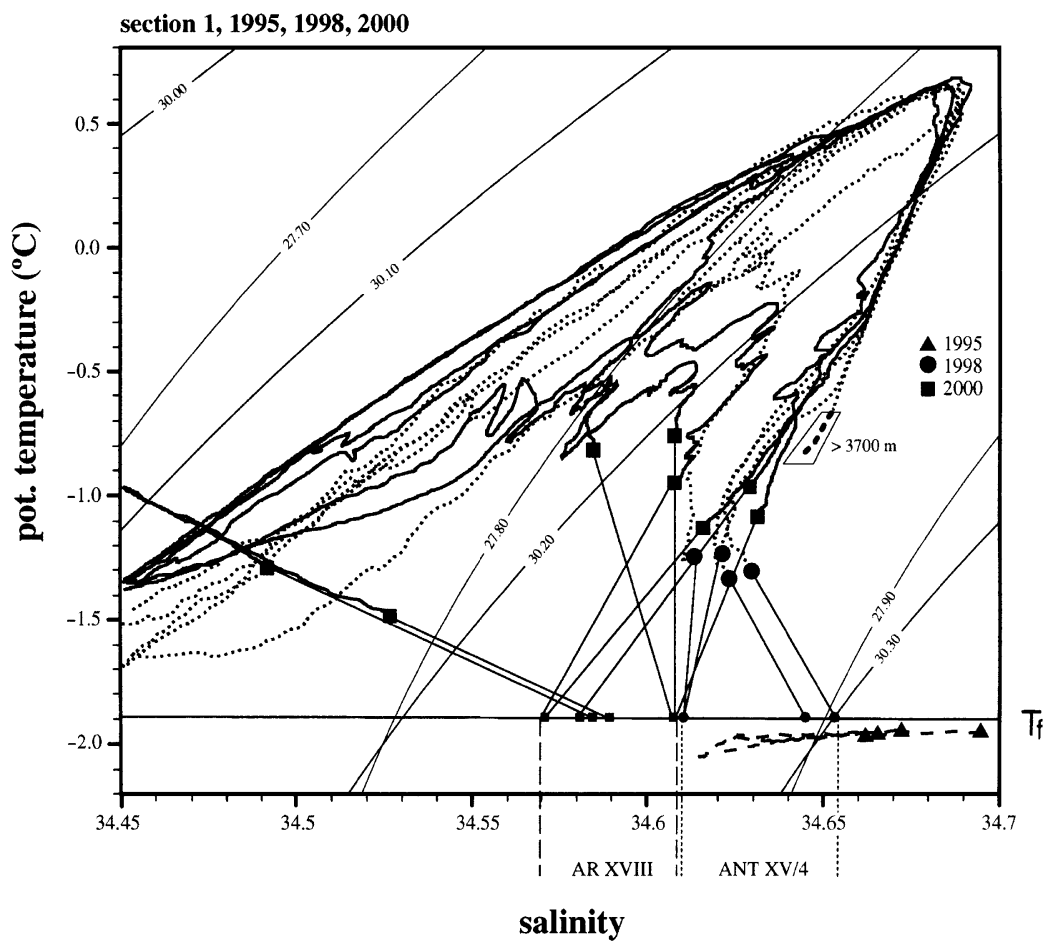

Fig. 9. Composed potential temperature vs. salinity $(\theta / S)$ diagram from the continental slope off the AP for the years 1998 (dotted line/filled dots) and 2000 (solid line/filled squares), and north of the Filchner Trough for 1995 (dashed line/filled triangles). The latter covers descending Ice Shelf Water. Tangents to the end curvatures, marked by symbols for corresponding years (see insert), are drawn to identify possible source water masses at the surface freezing point $\left(T_{\mathrm{f}}\right)$. Vertical lines (dashed) below $T_{\mathrm{f}}$ mark the salinity ranges of the source waters for AR XVIII and ANT XV/4 with a threshold salinity of $S=34.610$. The small trapezoid represents the $1998-\theta / S$ space for WSBW at the base of the continental slope $(>3700 \mathrm{~m})$. Isopycnals are drawn relative to the surface and to $500 \mathrm{~m}$.

for temperatures $<-1.1^{\circ} \mathrm{C}$. In contrast, the 2000 data follow more or less a straight line in the temperature range from $-0.5^{\circ} \mathrm{C}$ to the nearbottom minimum. To find the $\theta / S$-range of the source waters, we extend the bottom values (marked as circles for 1998 and squares for 2000) towards the surface freezing point $\left(T_{\mathrm{f}}\right)$ applying a tangent to the data of the lowest $150-200 \mathrm{~m}$. This assumes that the near-bottom trend represents the mixing of salty shelf waters with pycnocline waters at the continental shelf break (Foster and Carmack, 1976; Gordon, 1998). At the surface freezing point, the salinity range for both years is different: $34.610<S<34.646$ for 1998 (small circles) and $34.564<S<34.608$ for 2000 (small squares), with $S \sim 34.61$ as the threshold value. The latter is also the end point of the tangent to the inner Weddell Sea WDW/WSDW mixing line for the temperature range $-0.3^{\circ} \mathrm{C}$ to $0.2^{\circ} \mathrm{C}$. This indicates that waters with $S \sim 34.61$ are abundant and/or preferred for the formation of deep- and bottom-water at the continental shelf break. Deviations from this value produce either fresher/shallower or saltier/deeper WSBW components. Adding the data of ANT XII/3 (February 1995) (Grosfeld et al., 2001) from the sill of the Filchner Trough shows that the overflow water covers exactly the freezing point range of 1998 but lies outside of the year-2000 range (Fig. 9).

This comparison does not imply that Filchner Trough outflow is responsible for the saline WSBW component above $2500 \mathrm{~m}$ off the AP, because this water had already descended to depths $>3300 \mathrm{~m}$ when arriving at the northwestern 
Weddell Sea (Fahrbach et al., 2001). However, we want to emphasize that the interaction of saline shelf waters with ice shelves north of FilchnerRonne Ice Shelf (e.g., Larsen Ice Shelf) also could provide this dense source water. Bathymetric data from the western Weddell Sea continental shelf (Domack et al., 2001) show that deep depressions underneath ice shelves are more common than just for the Filchner-Ronne Ice Shelf. Due to the recent disintegration of Larsen $\mathrm{A}$ and the large calving event at Larsen B (Skvarca et al., 1999), significant variations in the modification of the western shelf waters could have caused the observed differences.

Evidence for high variability in the bottom waters of the western Weddell Sea, but on short space/time scales, results from the data (not shown) of cruise ANT X/7 (February 1993). Only 1 week apart, two sections were occupied at almost the same stations as in 1998 , and along $\sim 69^{\circ} \mathrm{S}$ from the continental shelf into the deep Weddell Basin (Fahrbach et al., 1995). On the continental slope at $69^{\circ} \mathrm{S}$, the near-bottom part of the $\theta / S$ curves tended towards a benthic salinity maximum. This shape is almost identical with the nearbottom curvatures observed in the same region almost a year before (ISW-1; Gordon, 1998), and at the tip of the peninsula in 1998 (Fig. 9). At the tip, however, the benthic salinity maximum was missing in 1993, as was the case in 2000 (AR XVII), but without a significant temperature increase (Fig. 10). Therefore, we assume that south of $69^{\circ} \mathrm{S}$ the water masses were formed responsible for the benthic salinity maximum in 1993. This signal travels according to the measurements by Fahrbach et al. (1995) within one season to the tip of the peninsula. A source for the salty WSBW component exists north of the Ronne Basin where High Salinity Shelf Water spills over the continental shelf break (Gordon et al., 1993).

Additional evidence for high interannual variability of dense bottom-water characteristics in the northwestern Weddell Sea comes from several CTD measurements at nearly the same location. All stations are within a $5.5-\mathrm{km}^{2}$ with $2800-2900 \mathrm{~m}$ depth representing six different years from 1989 to 2000 (Fig. 10). The square also contains the position of mooring AWI 207, which was located
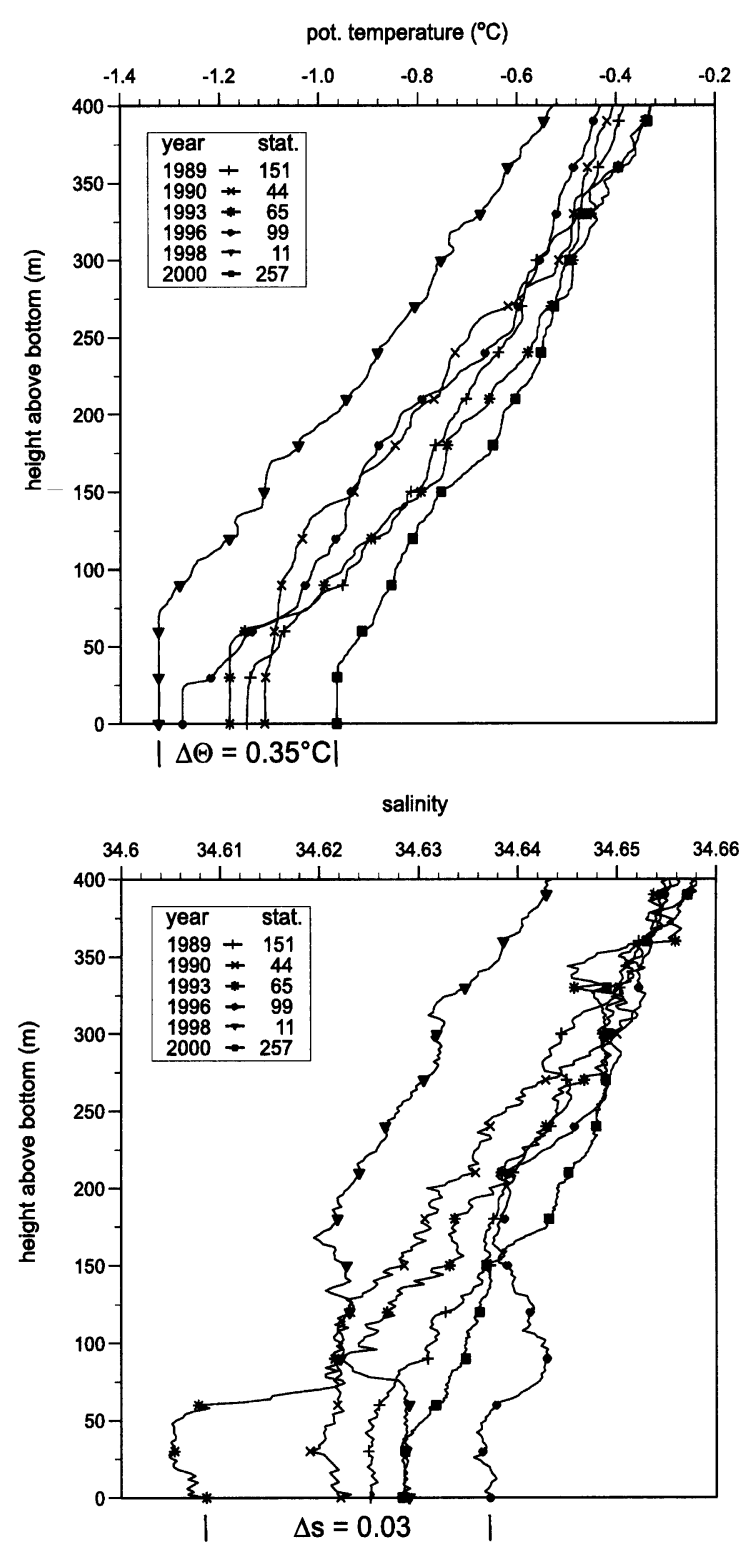

Fig. 10. Potential temperature (top) and salinity (bottom) profiles of the lowest $400 \mathrm{~m}$ above bottom near mooring position AWI 207 for different years listed in the insert. Maximum ranges ( $\Delta$ ) observed so far are shown at the bottom.

in the center of the WSBW plume and which did not change its position for several years. The data of AWI 207 are described in detail in v.Gyldenfeldt et al. (2002). Maximum changes of near-bottom $\theta$ and $S$ were $\sim 0.35^{\circ} \mathrm{C}$ and 0.03 , 


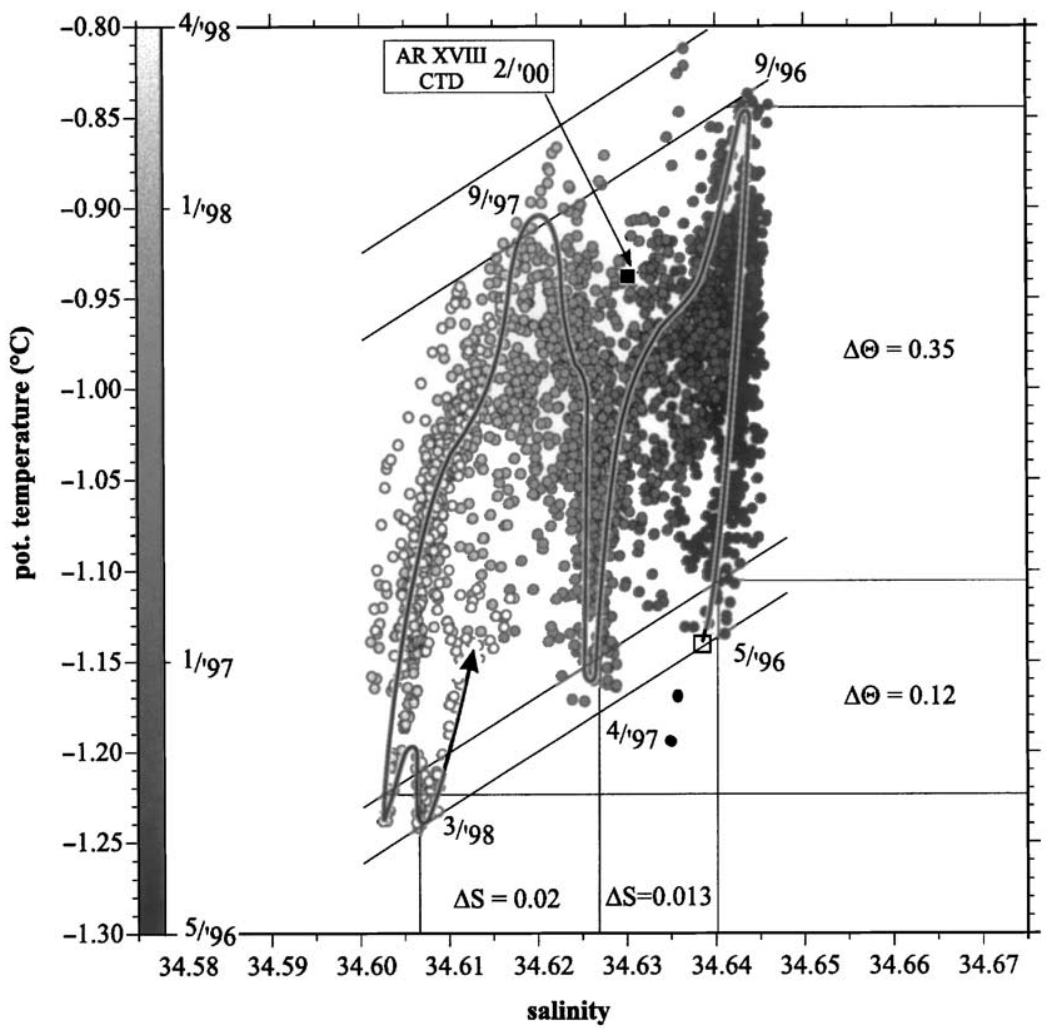

Fig. 11. Temporal evolution of potential temperature and salinity in $\theta / S$ space at the continental slope off the AP as recorded from May, 1996, to end of March, 1998, by the lowest instrument (50 m above bottom) of mooring AWI 207 (modified from v.Gyldenfeldt et al., 2002). Seasonal, interannual (for salinity), and bi-annual (for potential temperature) ranges are provided as $\Delta$-values. For salinity, seasonal and interannual ranges are almost identical due to the changes occurring mostly from late winter to late summer. The open square marks the starting point, the filled square represents the $\theta / S$ values measured in 2000 at CTD station 257 (coinciding with mooring position AWI 207) $50 \mathrm{~m}$ above bottom.

respectively, with the former occuring just within the 2-year period from 1998 to 2000. The continuous evolution in $\theta / S$ space over $\sim 2$ years (May 1996 to March 1998) retrieved from the lowest $(2455 \mathrm{~m})$ instrument of AWI 207 in the core of the cold, newly formed WSBW plume (Fahrbach et al., 1995) shows a strong seasonal signal (Fig. 11, modified from von Gyldenfeldt et al., 2002). The ranges in potential temperature and salinity were $\theta=0.35^{\circ} \mathrm{C}$ and $S=0.02$, respectively, with highest temperatures in winter (September) and lowest at the end of summer (April/ May). Within a 1-year cycle the salinity decreased mainly during summer (September to May) and less during winter. For the 2-year record, the seasonal signal was underlain by a longer negative trend in temperature $\left(\Delta \theta \sim 0.12^{\circ} \mathrm{C}\right)$ and salinity $(\Delta S \sim 0.03)$. However, at the end of the record this trend reversed and continued as the $\theta / S$ characteristics of the CTD measurements in 2000 at the same location and depth indicate (filled square in Fig. 10). Based on this data set it becomes obvious that the variability measured in the bottom layer along the northwestern continental slope can be explained in part by seasonal variation of WSBW characteristics.

The variations in WSBW characteristics observed off the tip of the peninsula also have consequences further downstream, i.e. at the southern flank of the SOP (Fig. 12) and in the passages through the South Scotia Ridge. In 1998, and for comparison 1992 (ANT X/4, winter 


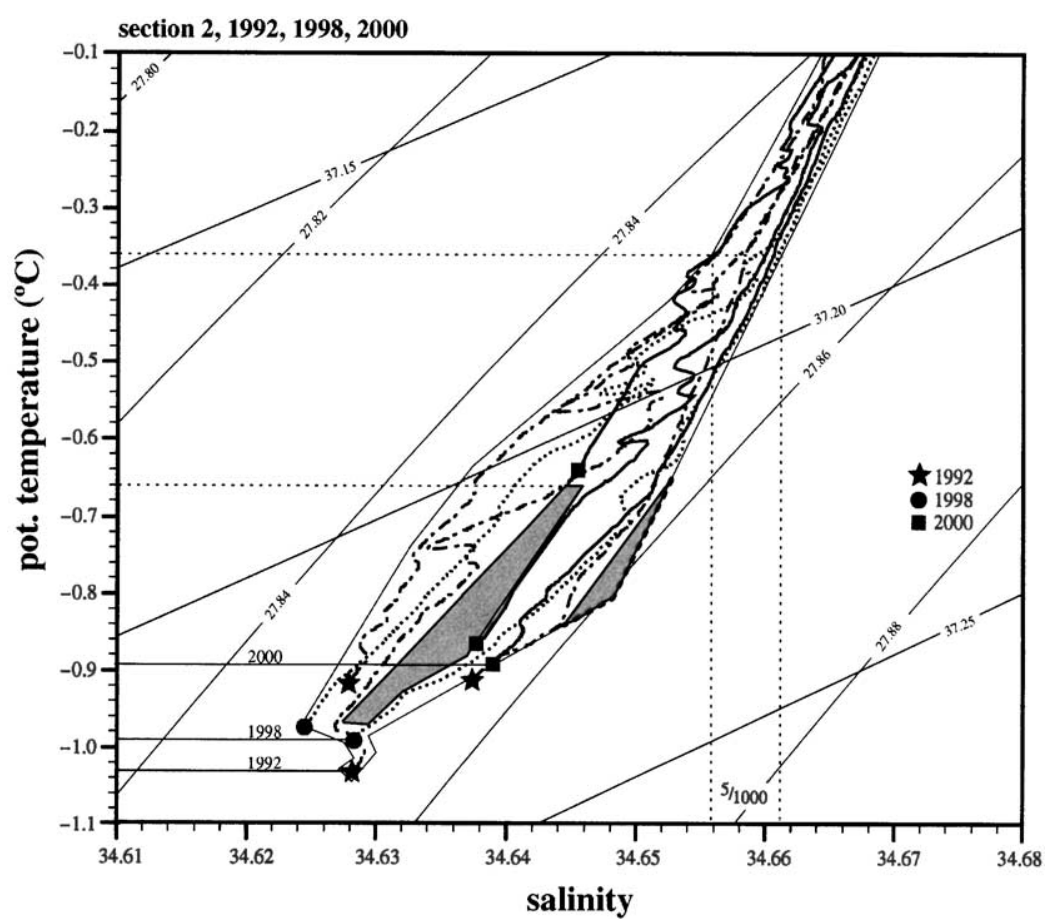

Fig. 12. Near-bottom potential temperature vs. salinity $(\theta / S)$ diagram for the continental slope south of SOP composed for the years 1992 (dotted-dashed/filled stars), 1998 (dotted/filled dots), and 2000 (solid/filled squares), indicating the temporal variability and the bifurcation (see also Fig. 7) in the bottom layer of the northwestern Weddell Sea. Minimum temperatures of the different years are marked by horizontal lines (lower left). The hatched areas represent $\theta / S$ spaces not covered by any data (central) or by WSBW in the deep Weddell Sea (right). The dashed line at the right border represents $\theta / S$ curves for WSBW of the interior $(>4500 \mathrm{~m}) \mathrm{Weddell} \mathrm{Sea}$. Isopycnals are drawn relative to the surface $\left(\sigma_{0}\right)$ and to $2000 \mathrm{~m}\left(\sigma_{2}\right)$.

cruise), the deep $\theta / S$-regime was divided across the Endurance Ridge into two types of WSBW which were located on either side of the ridge, and were characterized by different salinities. During AR XVIII (2000), we only observed the more saline bottom component on both sides of Endurance Ridge as already shown in Fig. 7. Since its southwestern tip is located far south of the western slope of SOP (Fig. 1a), bottom waters travelling through Powell Basin and to the south of it can both enter Jane Basin. With this sea-floor topography, bottom waters found south of Endurance Ridge seem to represent solely the deep characteristics of the central Weddell Sea, far from the influence of the rim current. This flow pattern agrees well with the model results of Schodlok et al. (2002), which show a bifurcation of the bottom flow at the southern entrance of Powell Basin. The low-salinity component that in 1998 fills Jane Basin (Fig. 1a) below $3500 \mathrm{~m}$ can escape from the Weddell Sea through Orkney Passage, freshening the bottom waters of the Scotia Sea (Gordon et al., 2001; Naveira Garabato et al., 2002; Schodlok et al., 2002). The more saline component, however, spreads eastward with the northern limb of the Weddell Gyre. The missing fresher WSBW and the related small differences across Endurance Ridge in 2000 indicate that Jane Basin, and perhaps even the whole Powell Basin, was filled with "central" WSBW. The different minimum temperatures (coldest in 1992 and warmest in 2000, Fig. 12) and the absence of the fresh type of WSBW in year 2000 all influence the flow through the northern passages and may be related to the rapid changes observed in the bottom water characteristics of the Scotia Sea (Rubython et al., 2001; Meredith et al., 2001). 


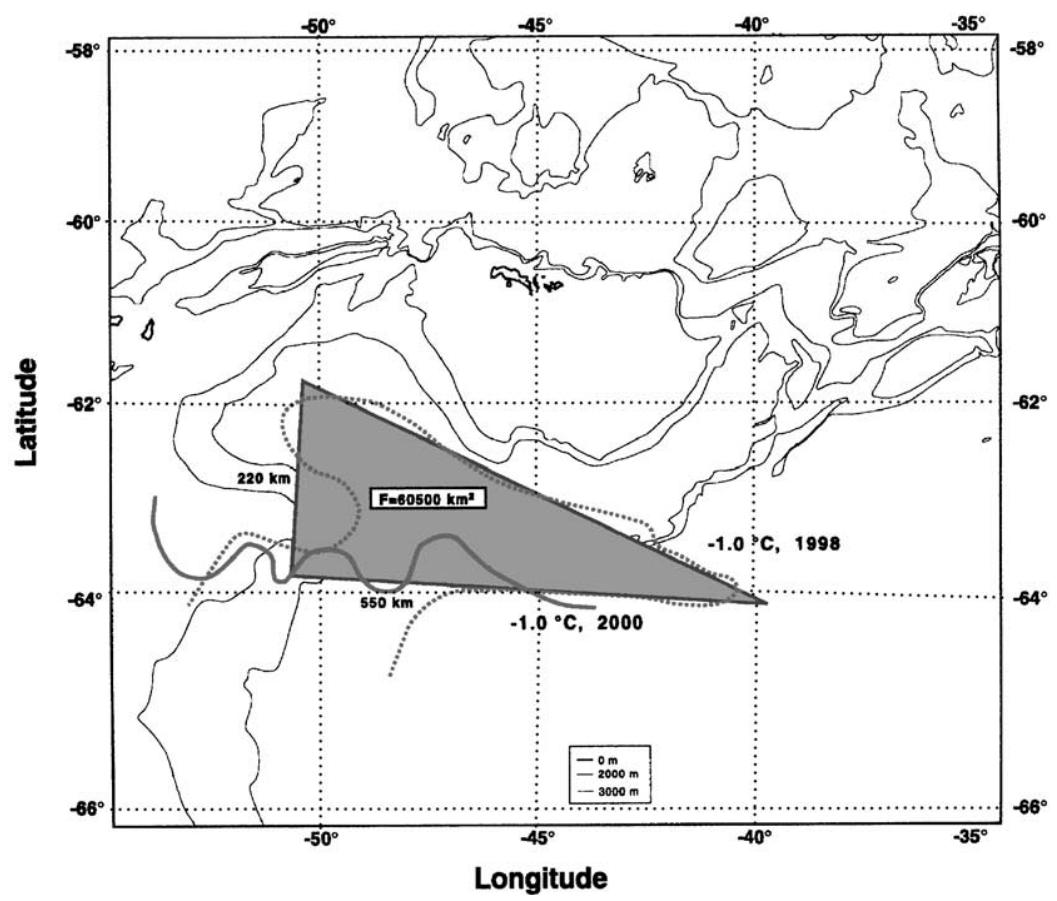

Fig. 13. Schematic illustration of the calculation conducted to determine the bottom water formation rate necessary to explain the differences in bottom potential temperature distributions (shaded area) as observed in 1998 and 2000 (see also Fig. 8).

To evaluate the maximum amount of water necessary to cause the near-bottom differences as observed in the northwestern Weddell Sea between 1998 and 2000 (Fig. 8a and b), we calculated the volume of a triangle marked by the $-1.0^{\circ} \mathrm{C}$ isoline of 1998 (Fig. 13). This assumes the most dramatic change in the deep Powell Basin being totally filled with waters warmer than $\theta=-1.0^{\circ} \mathrm{C}$ in 2000 . Less water is required if a lens of cold water would have survived in the central Powell Basin, with the warming affecting only the rim current and downstream regions. The triangle has an area of $60,500 \mathrm{~km}^{2}$. With an average thickness of $100 \mathrm{~m}$, a typical upper value for bottom water with $\theta<-1.0^{\circ} \mathrm{C}$ in this region, the volume of the bottom layer amounts to $6000 \mathrm{~km}^{3}$. To fill this volume within 2 years a transport rate of $3000 \mathrm{~km}^{3} /$ a, equivalent to $95,129 \mathrm{~m}^{3} / \mathrm{s}(=0.1 \mathrm{~Sv})$, is needed. Even if filled within one season, the required transport of $0.4 \mathrm{~Sv}$ nonetheless agrees remarkably well with the seasonal variance of the mean flow of newly formed bottom water in the northwestern Weddell Sea of $1.3 \pm 0.4 \mathrm{~Sv}$
(Fahrbach et al., 2001). This estimate indicates that an intermittent WSBW production by small sources along the Weddell Sea's periphery can account for the variability measured in the bottom layer of the northwestern Weddell Sea.

\section{Conclusions}

The comparison of hydrographic data from two cruises separated only by 2 years (1998 and 2000) shows a warming of the bottom layer at the entrance to Powell Basin by $\sim 0.3^{\circ} \mathrm{C}$. Further downstream, south of the South Orkney Plateau, temperatures increased slightly less by $\sim 0.2^{\circ} \mathrm{C}$, but here the fresher northern WSBW branch was absent. Interannual variability (Fig. 10) and the time lag between both sites, which amounts to several months (Schodlok et al., 2002), are believed to be responsible for the differences in water-mass characteristics. At Endurance Ridge, water masses that have the same "history" at the tip of the AP are decoupled due to the different 
pathways in combination with different travel times. This is sufficient to cause different bottomwater characteristics on either side of the ridge.

A simple calculation revealed that the observed changes can be explained in terms of bottom water transport fluctuations of up to $0.4 \mathrm{~Sv}$, equivalent to the seasonal variability of total WSBW transport along the western Weddell Sea continental slope (Fahrbach et al., 2001). An additional hint that the observed changes might result from short-term (seasonal) fluctuations comes from a 2-year time series of near-bottom temperature and salinity recorded at the continental slope off the AP (von Gyldenfeldt et al., 2002). The record was dominated by a constant seasonal temperature change of $\Delta \theta=0.35^{\circ} \mathrm{C}$, while variable for salinity ranging from 0.013 to 0.02 . Since the salinity changes were small during winter, the seasonal and interannual variability was almost identical. Over the 2-year period, the changes amounted to $\Delta \theta=0.12^{\circ} \mathrm{C}$ and $\Delta S=0.033$.

Evidence seems to exist that seasonal variability is responsible for the changes found in the deep northwestern Weddell Sea. However, such variability cannot explain that equivalent bottom-water characteristics were observed in different seasons (summer/winter), and variable bottom water characteristics were observed in the same season (summer) at same locations. In addition, it is unlikely that the different curvatures in $\theta / S$ space at great depth were caused solely by seasonal effects. Therefore, we favor as a possible explanation the intermittent activity of small sources along the Weddell Sea's periphery contributing shelf waters with different salinities to the deep and bottom water formation process. At this stage, we cannot exclude that seasonal effects influence the behavior of the sources, particularly inasmuch as we expect greatest dense water formation as ice forms during early winter (Timmermann et al., 2002). However, regional changes of the environment like the stranding of icebergs or the retreat of ice fronts might have a greater impact on watermass characteristics and productivity.

Observations from the Filchner Trough sill show that the composition of the overflow changes with the position of giant icebergs stranded on the shallow Berkner Bank (Grosfeld et al., 2001).
Numerical studies indicate that basal melting and the characteristics of Ice Shelf Water (ISW) can change as a result of a major retreat of the ice shelf front (Saleck et al., 2002). Tracer studies carried out during 1992 in the western Weddell Sea point to an additional ISW source near Larsen Ice Shelf (Weppernig et al., 1996). Thus, the decay of Larsen A and the major calving event at Larsen B (Skvarca et al., 1999) since 1996 might have disturbed the modification of shelf waters such that less cold water participated in the western Weddell Sea bottom-water formation process. If the fate of Larsen Ice Shelf is responsible for the near-bottom changes further north, the warming could continue considering the residence time of waters on the continental shelf of $\sim 5$ years (Mensch et al., 1998). A preliminary analysis of the data of cruise AR XIX onboard NApOc Ary Rongel (17 January to 8 February, 2001) shows bottom temperatures higher by $\sim 0.16^{\circ} \mathrm{C}$ than in 1998 in central Powell Basin, and nearly the same temperatures as in 2000 in the rim current. The latter observation is consistent with our assumptions made for calculating the transports necessary to cause the observed changes in the near-bottom layer. However, with such variability dominating the northwestern Weddell Sea, bottom-temperature distributions from different years have to be compiled with caution (e.g., Gordon et al., 2001).

Our results are not consistent with a long-term warming of Weddell Sea's deep and bottom waters as identified for WDW and upper WSDW (Robertson et al., 2002). We might have missed this warming trend for the deep water due to an inadequate choice of stations. However, for the bottom water the coverage in space and time was appropriate. Therefore, we conclude that the observed near-bottom variability in the northwestern Weddell Sea is caused by fluctuations in composition and/or volume of the parent waters participating in bottom water formation further south. We cannot exclude that the observed warming at shallower levels might already influence the shelf waters and/or might propagate downwards in the water column. However, this process occurs on time scales longer than the 2 years during which the deep northwestern Weddell Sea experienced a significant warming. Since 
today's changes already influence the deep and bottom water flow into the Scotia Sea and beyond, it is desirable to continue the monitoring of a region which serves as a hydrographic switch with global importance.

\section{Acknowledgements}

We thank the officers, scientists, and crew of $F S$ Polarstern and NApOc Ary Rongel for their assistance during the cruises ANT XV/4 (1998) and AR XVII (2000), respectively. We are grateful to E. Fahrbach for providing the CTD system for cruise AR XVIII, A. Belem for various support prior and during AR XVIII, and A. Wisotzki for helping during data processing and figure production. The manuscript benefited from the comments of M. Schodlok, R. Robertson, and R. Muench and the careful work of A. Naveira Garabato and two anonymous reviewers. Hydrographic work on AR XVIII and Absy's visit to Alfred Wegener Institute for data processing and analysis was funded by Conselho Nacional de Desenvolvimento Cientifico e Tecnologico (CNPq), Brasil.

\section{References}

Beckmann, A., Timmermann, R., 2001. Circumpolar influences on the Weddell Sea: indication of an Antarctic circumpolar coastal wave. Journal of Climate 14, 3785-3792.

Brennecke, W., 1921. Die ozeanographischen Arbeiten der deutschen antarktischen Expedition 1911-1912. Archiv Deutsche Seewarte 39, 1-216.

Carmack, E.C., 1977. Water characteristics of the Southern Ocean south of the Polar Front. In: Angel, M. (Ed.), A Voyage of Discovery, George Deacon 70th Anniversary Volume. Pergamon Press, Oxford, pp. 15-41.

Domack, E., Leventer, A., Gilbert, R., Brachfeld, S., Ishman, S., Camerlenghi, A., Gavahan, K., Carlson, D., Barkoukis, A., 2001. Cruise reveals history of Holocene Larsen Ice Shelf. EOS Transactions 82(2), 13, 16-17.

Fahrbach, E. (Ed.), 1999. The Expedition ANTARKTIS XV/4 of the research vessel Polarstern in 1998. Reports on Polar Research, 314, 109pp.

Fahrbach, E., Rohardt, G., Scheele, N., Schröder, M., Strass, V., Wisotzki, A., 1995. Formation and discharge of deep and bottom water in the northwestern Weddell Sea. Journal of Marine Research 53, 515-538.
Fahrbach, E., Harms, S., Rohardt, G., Schröder, M., Woodgate, R.A., 2001. Flow of bottom water in the northwestern Weddell Sea. Journal of Geophysical Research. 106, 2761-2778.

Foster, T.D., Carmack, E.C., 1976. Frontal zone mixing and Antarctic Bottom Water formation in the southern Weddell Sea. Deep-Sea Research 23, 301-317.

Foster, T.D., Middleton, J.H., 1979. Variability in the bottom water of the Weddell Sea. Deep-Sea Research 26, 743-762.

Georgi, D.T., 1981. Circulation and bottom waters in the southwestern South Atlantic. Deep-Sea Research 28, 959-979.

Gordon, A.L., 1966. Potential temperature, oxygen and circulation of bottom water in the Southern Ocean. DeepSea Research 13, 1125-1138.

Gordon, A.L., 1998. Western Weddell Sea thermohaline stratification. In: Jacobs, S.S., Weiss, R.F. (Eds.), Ocean, Ice, and Atmosphere. Antarctic Research Series 75, AGU, Washington DC, pp. 215-240.

Gordon, A.L., Huber, B., Hellmer, H.H., Ffield, A., 1993. Deep and bottom water of Weddell Sea's western rim. Science 262, 95-97.

Gordon, A.L., Mensch, M., Dong, Z., Smethie, W.M., de Bettencourt, J., 2000. Deep and bottom water of the Bransfield Strait eastern and central basins. Journal of Geophysical Research 105, 11337-11346.

Gordon, A.L., Visbeck, M., Huber, B., 2001. Export of Weddell Sea Deep and Bottom Water. Journal of Geophysical Research 106, 9005-9018.

Grosfeld, K., Schröder, M., Fahrbach, E., Gerdes, R., Mackensen, A., 2001. How iceberg calving and grounding change the circulation and hydrography in the Filchner Ice shelf/ocean system. Journal of Geophysical Research 106, 9039-9056.

Locarnini, R.A., Whitworth III, T., Nowlin Jr., W.D., 1993. The importance of the Scotia Sea on the outflow of Weddell Sea deep water. Journal of Marine Research 51, 135-153.

Mensch, M., Smethie Jr., W.M., Schlosser, P., Weppernig, R., 1998. Transient tracer observations from the western Weddell Sea during the drift and recovery of Ice Station Weddell. In: Jacobs, S.S., Weiss, R.F. (Eds.), Ocean, Ice, and Atmosphere. Antarctic Research Series 75, AGU, Washington DC, pp. 241-256.

Meredith, M.P., Naveira Garabato, A.C., Stevens, D.P., Heywood, K.J., Sanders, R.J., 2001. Deep and bottom waters in the eastern Scotia Sea: rapid changes in properties and circulation. Journal of Physical Oceanography 31, 2157-2168.

Muench, R.D., Hellmer, H.H., 2002. The international DOVETAIL Program: an overview. Deep-Sea Research II 49 (21), 4711-4714.

Naveira Garabato, A.C., McDonagh, E.L., Stevens, D.P., Heywood, K.J., Sanders, R.J., 2002. On the export of Antarctic Bottom Water from the Weddell Sea. Deep-Sea Research II 49 (21), 4715-4742. 
Orsi, A.H., Nowlin Jr., W.D., Whitworth III, T., 1993. On the circulation and stratification of the Weddell Gyre. Deep-Sea Research 40, 169-203.

Orsi, A.H., Johnson, G.C., Bullister, J.L., 1999. Circulation, mixing, and production of Antarctic bottom water. Progress in Oceanography 43, 55-109.

Reid, J.L., Nowlin Jr., W.D., Patzert, W.C., 1977. On the characteristics and circulation of the southwestern Atlantic Ocean. Journal of Physical Oceanography 7, 62-91.

Robertson, R., Visbeck, M., Gordon, A.L., 2002. Long-term potential temperature trends in the deep waters of the Weddell Sea. Deep-Sea Research II 49 (21), 4791-4806.

Rubython, K.E., Heywood, K.J., Vassie, J.M., 2001. Interannual variability of bottom temperatures in Drake Passage. Journal of Geophysical Research 106, 2779-2793.

Saleck, N., Hellmer, H.H., Fahrbach, E., 2002. On the influence of ice shelf edge position on circulation and water mass modification, FRISP Report, 14, Alfred Wegener Institute, Bremerhaven, Germany, in press.

Schodlok, M.P., Hellmer, H.H., Beckmann, A., 2002. On the transport, variability, and origin of dense water masses crossing the South Scotia Ridge. Deep-Sea Research II 49 (21), 4807-4825.

Schröder, M., 1994. Physical oceanography and nutrients on Polarstern cruise ANT X/4 (1992). In: Lemke, P. (Ed.), Reports on Polar Research., Vol. 140. Alfred Wegener Institute, Bremerhaven, Germany, pp. 15-34.

Schröder, M., 1997. Physical oceanography, nutrients, and tracers on Polarstern cruise ANT XII/3 (1995). In: Jokat, W., Oerter, H. (Eds.), Reports on Polar Research., Vol. 219.
Alfred Wegener Institute, Bremerhaven, Germany, pp. 1936.

Schröder, M., Fahrbach, E., 1999. On the structure and the transport in the eastern Weddell Gyre. Deep-Sea Research 46, 501-527.

Skvarca, P., Rack, W., Rott, H., Donangelo, T.L., 1999. Climatic trends and the retreat and disintegration of ice shelves on the Antarctic Peninsula: an overview. Polar Research 18, 151-157.

Smith, W., Sandwell, D., 1997. Global sea floor topography from satellite altimetry and ship depth soundings. Science 277, 1956-1962.

Timmermann, R., Beckmann, A., Hellmer, H.H., 2002. Simulation of ice-ocean dynamics in the Weddell Sea. Part I: model configuration and validation. Journal of Geophysical Research, in press.

von Gyldenfeldt, A.-B., Fahrbach, E., Garcia, MA., Schröder, M., 2002. Flow variability at the tip of the Antarctic Peninsula. Deep-Sea Research II 49 (21), 4743-4766.

Weppernig, R., Schlosser, P., Khatiwala, S., Fairbanks, R.G., 1996. Isotope data from Ice Station Weddell: implications for deep water formation in the Weddell Sea. Journal of Geophysical Research 101, 25723-25739.

White, W.B., Peterson, R.G., 1996. An Antarctic circumpolar wave in surface pressure, wind, temperature, and sea-ice extent. Nature 380, 699-702.

Whitworth III, T., Nowlin Jr., W.D., Locarnini, R.A., Smith, S.G., 1994. Weddell Sea shelf water in the Bransfield Strait and Weddell-Scotia Confluence. Deep-Sea Research 41, 629-641. 